\title{
Mineralogy of Non-Silicified Fossil Wood
}

\author{
George E. Mustoe \\ Geology Department, Western Washington University, Bellingham, WA 98225, USA; mustoeg@wwu.edu; \\ Tel.: +1-360-650-3582
}

Received: 21 December 2017; Accepted: 27 February 2018; Published: 3 March 2018

\begin{abstract}
The best-known and most-studied petrified wood specimens are those that are mineralized with polymorphs of silica: opal-A, opal-C, chalcedony, and quartz. Less familiar are fossil woods preserved with non-silica minerals. This report reviews discoveries of woods mineralized with calcium carbonate, calcium phosphate, various iron and copper minerals, manganese oxide, fluorite, barite, natrolite, and smectite clay. Regardless of composition, the processes of mineralization involve the same factors: availability of dissolved elements, $\mathrm{pH}$, Eh, and burial temperature. Permeability of the wood and anatomical features also plays important roles in determining mineralization. When precipitation occurs in several episodes, fossil wood may have complex mineralogy.
\end{abstract}

Keywords: fossil wood; mineralogy; paleobotany; permineralization

\section{Introduction}

Non-silica minerals that cause wood petrifaction include calcite, apatite, iron pyrites, siderite, hematite, manganese oxide, various copper minerals, fluorite, barite, natrolite, and the chromium-rich smectite clay mineral, volkonskoite. This report provides a broad overview of woods fossilized with these minerals, describing specimens from world-wide locations comprising a diverse variety of mineral assemblages. Data from previously-undescribed fossil woods are also presented. The result is a paper that has a somewhat unconventional format, being a combination of literature review and original research. In an attempt for clarity, the information is organized based on mineral composition, rather than in the format of a hypothesis-driven research report. Non-silica mineralized wood is described from world-wide localities; North American occurrences are emphasized simply because it is the region most familiar to the author.

The terminology "petrified wood" is used in preference to "permineralized wood". The latter term has commonly been used by paleobotanists to describe fossil wood, based on the long-standing presumption that wood fossilization commonly results from infilling of cellular tissues by mineral precipitates. Detailed analyses show that permineralization is, in fact, a relatively rare phenomenon; the percentage of original organic matter that is preserved in mineralized wood is generally very small [1].

The majority of the specimens described in this report are fossilized woods that consist almost entirely of non-silica minerals. Exceptions include woods where preservation resulted from successive episodes of mineralization, including silica precipitation. Examples described in this report range from dolomite wood that contains quartz-filled fractures (Washington, USA) to silicified wood that contains abundant copper minerals (Turkey "colla wood"). Another mineralogy variant involves pyrite or apatite crystals that have precipitated within cells, where the surrounding cell walls are carbonized or silicified. Photomicrographs are provided that illustrate examples of these mineralogies.

The tables of fossil wood occurrences presented in this paper should be considered as representative examples of various modes of wood mineralization, not complete inventories of every known locality. 
Previous Work

Few attempts have been made to review non-silicified petrified woods. One notable example is the work of a Dutch geologist, P. Buurman, who described silicified woods in detail, but also discussed calcite, dolomite, calcium phosphate, and various iron minerals as agents of wood petrifaction [2]. As noted below, many other authors have described specific occurrences of non-silica petrified wood. Processes of wood petrifaction have largely been interpreted using observations of silicified specimens. Detailed bibliographies can be found in two recent open-access publications $[1,3]$.

\section{Analytical Methods}

Most specimens illustrated in this report are from the author's research collection at the Geology Department, Western Washington University, Bellingham, Washington, USA. Specimen photos provided by other researchers are identified in the figure captions. Petrographic thin-section photos were taken with a Zeiss polarizing microscope equipped with a 5-megapixel digital camera. Scanning electron photomicrographs were made using a Tescan Vega SEM (Tesca, Brnu, Czech Republic). Mineral identifications were made using two methods: SEM/EDS elemental analyses obtained with an EDAX energy-dispersive XRF spectrometer running Genesis software (EDAX, Mahwah, New Jersey, USA) and X-ray diffraction patterns performed with a Rigaku Geigerflex diffractometer (www.Rigaku.com) using Ni-filtered $\mathrm{Cu}$ k-alpha radiation. XRD samples were prepared as packed powders.

\section{Carbonate Minerals: Calcite and Dolomite}

After silica, calcium carbonate is the most common form of wood petrifaction, with many known occurrences (Table 1). Carbonate mineralization typically occurs in formations that lack a source of dissolved silica, the most common Si sources being feldspars and volcanic glass [4].

Table 1. Woods mineralized with carbonate minerals.

\begin{tabular}{cccc}
\hline Mineralization & Age & Location & Reference \\
\hline Calcite & Jurassic & Lucków, Poland & {$[5]$} \\
Calcite & Cretaceous & Isle of Wight, England & {$[2]$} \\
Calcite & Cretaceous & Kansas, USA & {$[6]$} \\
Calcite & Eocene & Geiseltal, Germany & {$[7]$} \\
Calcite & Eocene & British Columbia, Canada & This report \\
Calcite & Eocene & Ellesmere Island Arctic Canada & {$[8]$} \\
Calcite & Miocene & Washington, USA & {$[9]$} \\
Calcite & Neogene & Florida, USA & {$[1]$} \\
Calcite & Pliocene & Dunrobba, Italy & {$[10]$} \\
Calcite & Pleistocene & California, USA & {$[11,12]$} \\
Calcite & Pleistocene & Weimar, Germany & {$[13]$} \\
Calcite & Pleistocene & California, USA & {$[14,15]$} \\
Calcite & Pleistocene & Northern Iceland & {$[16]$} \\
Dolomite & unknown & Germany & {$[17]$} \\
Dolomite & unknown & Hungary & {$[18]$} \\
Dolomite & Eocene & Washington, USA & This report \\
\hline
\end{tabular}

Carbonate-mineralized plants include both petrified wood (Figure 1) and foliar and reproductive remains preserved within calcareous concretions, e.g., coal balls. Carbonate-mineralized tissues may preserve large amounts of original tissue, in contrast to silicified woods, which commonly contain very little relict organic matter [1,19]. However, in some deposits wood mineralized with calcium carbonate contains only small amounts of organic matter (Figure 2). This variation in the organic matter: calcium carbonate ratio may reflect the rate of mineralization versus the rate of tissue degradation, the same phenomenon that controls preservation of organic matter in silicified wood. When wood is mineralized rapidly, tissues may not have had time to have undergone decomposition. Also, as noted 
later, carbonate mineralization occurs under $\mathrm{pH} /$ Eh levels that are less destructive to organic matter than the conditions that favor silica precipitation.

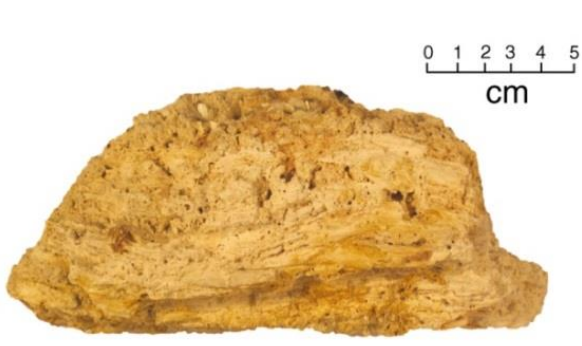

A

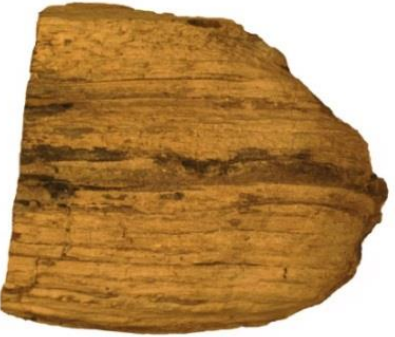

B

Figure 1. Woods mineralized with calcite. (A) Middle Pleistocene mangrove root, Acicennica nitida, Sarasota County, Florida, USA; (B) Late Cretaceous wood, Nanaimo Group, Vancouver Island, British Columbia, Canada.

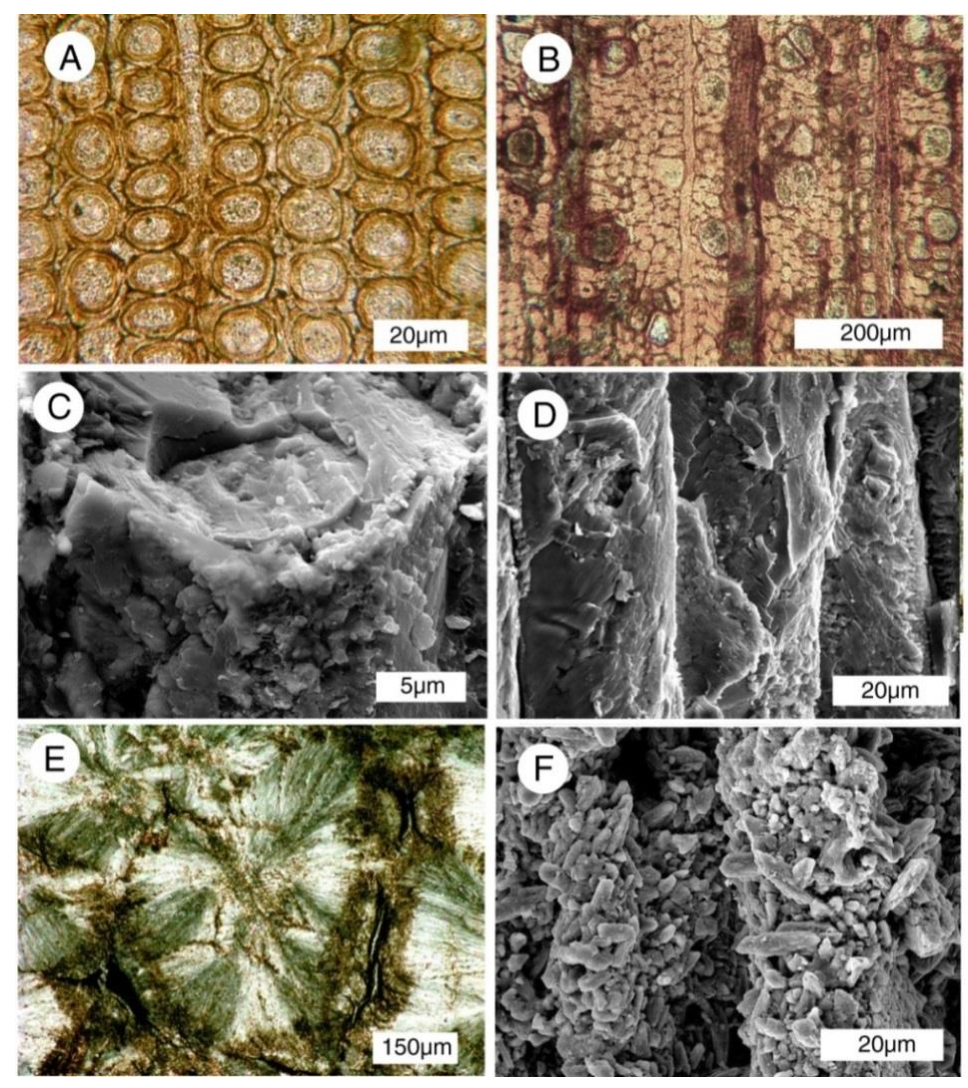

Figure 2. Calcite mineralized fossil wood. (A-E) are from Upper Cretaceous Nanaimo Group, Vancouver Island, British Columbia, Canada. (A) Specimen from Puntledge River, transverse orientation. (B) Specimen from Collishaw Point, Hornby Island, transverse orientation. Relict organic matter (as evidenced in acetate peels) causes thin cell walls to be brownish red; (C) SEM view of a single tracheid of Puntledge River wood. Cell wall appears thick because of microcrystalline calcite. Lumina are filled with more coarsely crystalline calcite; (D) SEM view, specimen from Port Moody, tangential orientation. Relict smooth surfaces of cell walls are mineralized with calcite; (E) Port Hardy specimen, transverse orientation. Polarized light illumination shows radiating calcite crystals that have disrupted cellular tissue; (F) Neogene wood from Glades County, Florida, USA. Tangential orientation, showing tracheid walls mineralized with coarsely-crystalline calcite. 


\section{Dolomite Wood}

Dolomite has infrequently been reported as a component of carbonate-mineralized wood (Table 1). Dolomitization of wood is rare because $\mathrm{Mg}$ is highly water soluble in most near-surface terrestrial and lacustrine environments; therefore, dolomitized wood is most likely to occur in wood buried in marine or brackish water sediments, which may have high $\mathrm{Mg}$ content.

A notable example is the Eocene Puget Group in northwestern Washington, USA. These strata are composed of fluvial and deltaic deposits that were deposited during an era of subtropical climate. Fluvial sediments deposited along an ancient meandering river and adjacent floodplain are the dominant component, but transgressive interbeds include brackish water coastal sediments [20]. Fossil wood is locally abundant in coal-bearing sequences, and this wood is mineralized with dolomite (Table 2, Figure 3). Fractures in the wood are commonly filled with crystalline quartz that precipitated during a later phase of mineralization. Large carbon peaks are present in SEM/EDS spectra for both samples, but this low atomic mass element cannot be quantitatively determined. Despite this issue, the data are useful for showing the high abundance of calcium and magnesium, indicative of dolomite.

Table 2. Major element composition of dolomitized wood from Eocene Puget Group, King County, Washington, USA, determined by SEM/EDS.

\begin{tabular}{|c|c|c|}
\hline Oxide & $\begin{array}{l}\text { Issaquah } \\
\text { Weight \% }\end{array}$ & Atomic \% \\
\hline $\mathrm{MgO}$ & 32.6 & 41.2 \\
\hline $\mathrm{Al}_{2} \mathrm{O}_{3}$ & 4.8 & 2.4 \\
\hline $\mathrm{SiO}_{2}$ & 5.3 & 4.5 \\
\hline $\mathrm{CaO}$ & 55.7 & 51.9 \\
\hline $\mathrm{Fe}_{2} \mathrm{O}_{3} *$ & 0 & 0 \\
\hline \multicolumn{3}{|c|}{ Black Diamond Coal Mine } \\
\hline $\mathrm{MgO}$ & 29.8 & 38.1 \\
\hline $\mathrm{Al}_{2} \mathrm{O}_{3}$ & 0.74 & 0.38 \\
\hline $\mathrm{SiO}_{2}$ & 3.6 & 3.1 \\
\hline $\mathrm{CaO}$ & 56.3 & 51.7 \\
\hline $\mathrm{Fe}_{2} \mathrm{O}_{3}$ * & 0.52 & 6.8 \\
\hline
\end{tabular}
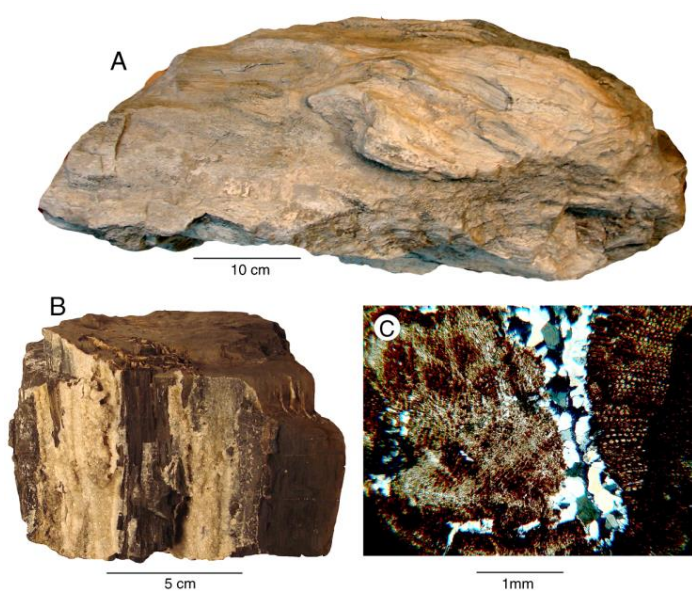

Figure 3. Dolomite wood from Eocene Puget Group, King County, Washington, USA. (A) Log from John Henry Coal Mine, Black Diamond, Washington; (B) dolomitized wood fragment showing megascopic crystalline quartz (light colored) deposited in fractures. From coal-bearing beds near Issaquah, Washington; (C) Thin section of Issaquah wood, composed of dolomitized tissue with microcrystalline quartz filling fractures. 


\section{Calcium Phosphate}

Calcium phosphate (as hydroxyapatite) occurs widely in vertebrate animals, where it provides the inorganic scaffold for bones and teeth. Other forms of phosphorus are found in all living creatures, being present in cell membranes and in adenosine triphosphate (ATP), an essential mediator for intracellular energy transfer. Availability of phosphorus as a nutrient is commonly a limit for growth in biotic communities; low concentrations of this element in most ground and surface waters explain the scarcity of phosphatized petrified wood. High levels of dissolved phosphorus in some marine environments explain occurrences of phosphatized wood, e.g., Middle Jurassic wood from Svalbard (Boreal Realm) [21,22] and the Pacific sea floor [23]. Plant remains preserved in freshwater phosphatic nodules near Queensland, Australia have been inferred to result for phosphate dissolved from abundant insect remains and local guano deposits [24]. Known occurrences of phosphatized wood are listed in Table 3.

Table 3. Phosphatized wood occurrences.

\begin{tabular}{cccc}
\hline Location & Age & Setting & Reference \\
\hline Foy, France & Carboniferous & Continental & {$[2]$} \\
Illinois, USA & Jurassic & Continental & {$[25]$} \\
Svalbard, Boreal Realm & Jurassic & Marine & {$[21,22]$} \\
Swindon, England & Jurassic & Marine & {$[10]$} \\
Antarctica & Cretaceous & Continental & {$[26]$} \\
Winterswijk, Netherlands & Cretaceous & Continental & {$[2]$} \\
New Mexico, USA & Cretaceous & Continental & {$[27]$} \\
California, USA & Eocene & Continental & {$[28]$} \\
Australia & Miocene/Oligocene & Continental & {$[23]$} \\
Nevada, USA & Miocene & Continental & {$[28]$} \\
Idaho, USA & Miocene & Continental & {$[28]$} \\
Mt. Elgon, Uganda & Miocene/Pliocene & Continental & {$[29]$} \\
Florida, USA & Neogene & Continental & {$[28]$} \\
Republic of Chad & Pliocene/Pleistocene & Continental & {$[30]$} \\
Northern Iceland & Pleistocene & Continental & {$[16]$} \\
Pacific sea floor & Holocene & Marine & {$[23]$} \\
\hline
\end{tabular}

Figure 3 shows two examples of Miocene wood, both mineralized with carbonate-fluorapatite. Specimen shown in Figure 4A was collected by the author from a site within the Virgin Valley Formation lacustrine strata in northwestern Nevada, USA. The preservation of this specimen is puzzling, because the silty bed in which it is found is a source of abundant opalized wood that was fossilized via dissolved silica released from rhyolitic tephra. The abundance of silica in these lakebed sediments is also evidenced by thick interlayers of diatomite. Phospatization presumably resulted from a localized geochemical anomaly, where silica precipitation was inhibited. As a further mystery, the same strata yielded a wood specimen (described later in this report) that is mineralized with Fe-Mn oxides.

Abundant phosphatized wood in Miocene lakebeds at Bruneau, Idaho, USA are homogeneous in composition, consisting of carbonate-fluorapatite [28]. At this locality, fossilized driftwood (Figures 4B and 5A) occurs within a single thin sandstone bed that was deposited as a cataclysmic debris torrent [28]. The fossil wood displays moderately well-preserved anatomical detail (Figures 5B and 6). 

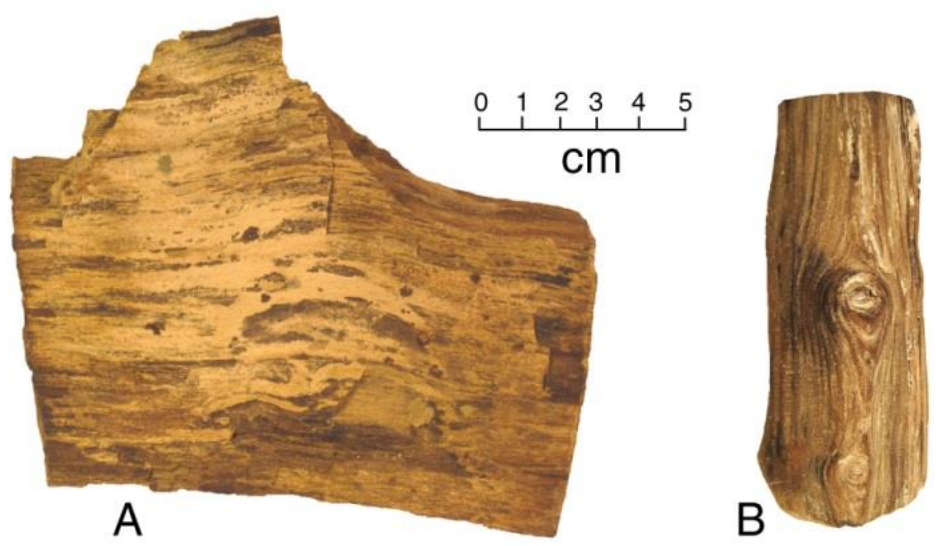

Figure 4. Miocene phosphatized wood. (A) Gooch Table, Virgin Valley, Nevada, USA; (B) Bruneau, Idaho, USA.
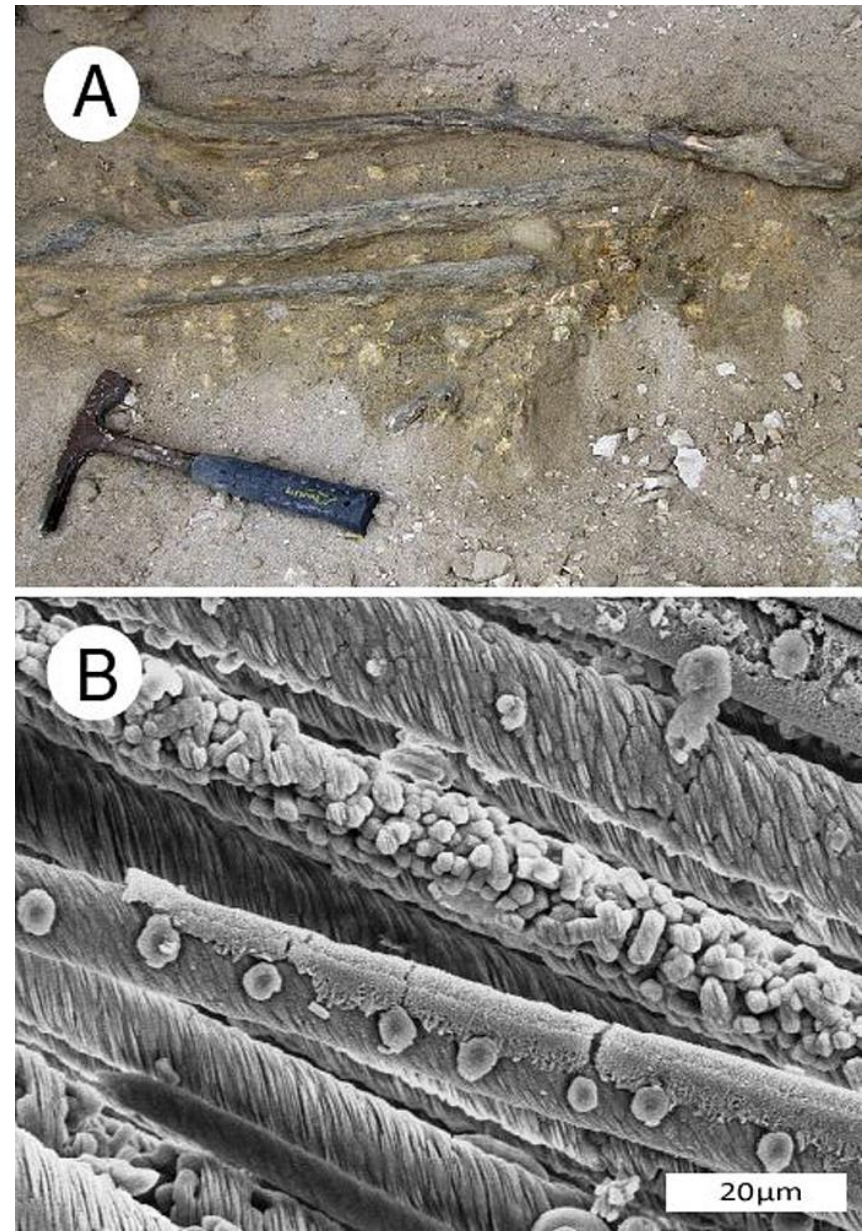

Figure 5. Phosphatized Miocene wood from Bruneau, Idaho, USA. (A) Driftwood limbs in lacustrine sediment; (B) SEM image showing tracheids mineralized with carbonate fluorapatite. Radial view. Spiral texture characterizes reaction wood, where asymmetric growth occurs in trees growing non-vertically. One tracheid shows circular casts of intertracheid pits, an adjacent tracheid is filled with blocky apatite crystals. 


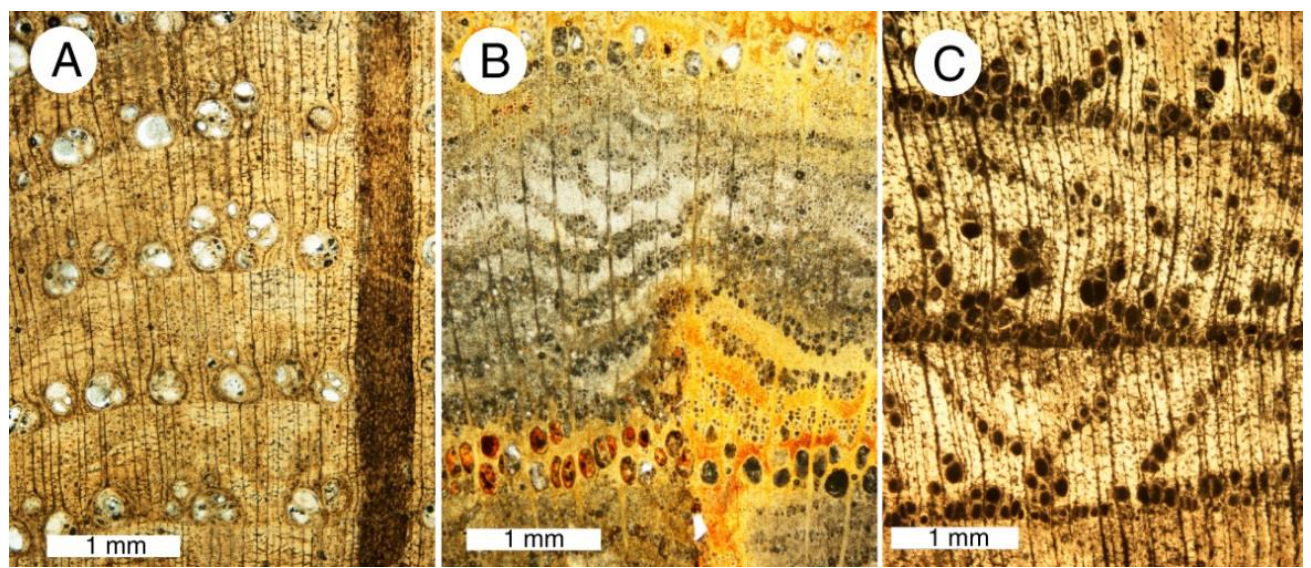

Figure 6. Thin sections of phosphatized angiosperm wood from Bruneau, Idaho USA, transverse orientation. (A) Carya sp.; (B) Ulmus sp.; (C) unidentified hardwood. Photos courtesy of T.A. Dillhoff, used with permission.

SEM photos document wide variability in the styles of mineralization, ranging from complete replacement of tissues with microcrystalline calcium phosphate (Figure $7 \mathrm{~A}-\mathrm{C}$ ) to specimens that contain radiating crystalline masses (Figure 7D) and euhedral apatite crystals attached to surfaces of carbonized cell walls (Figure 7E,F).

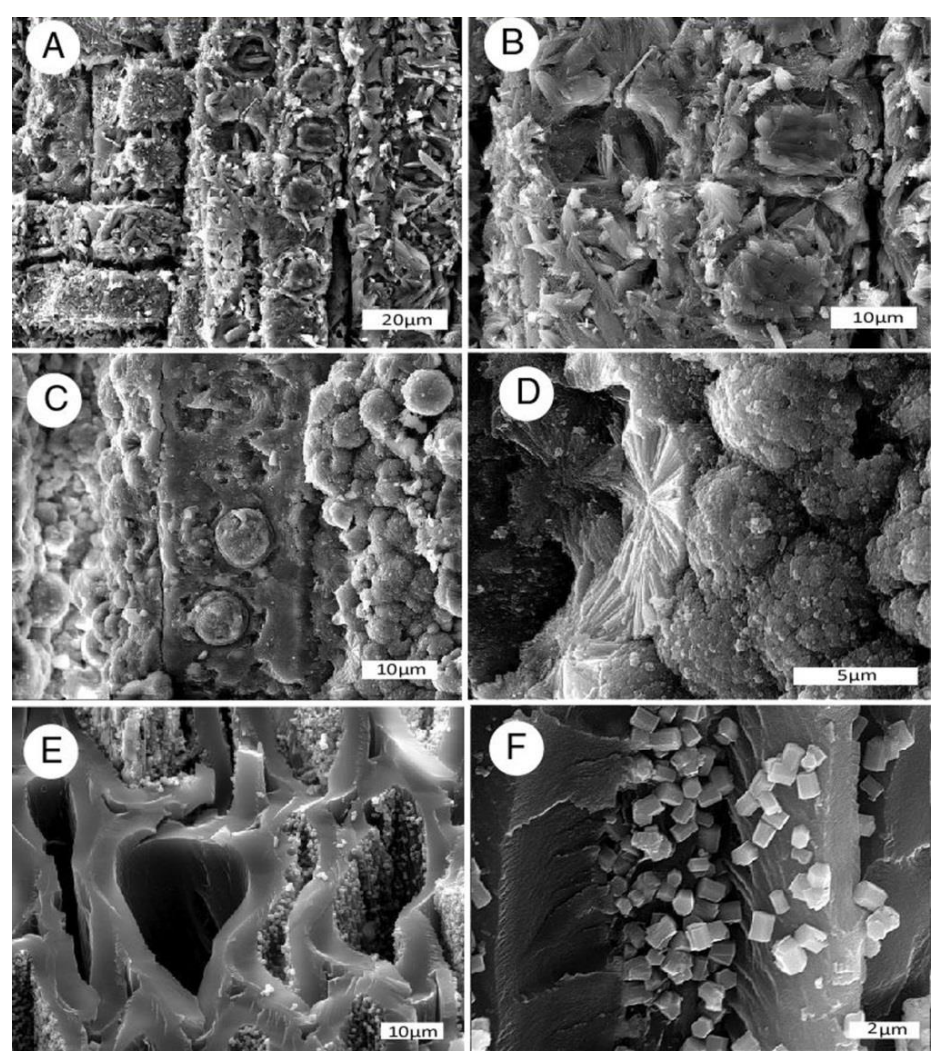

Figure 7. Phosphatized wood. (A,B) carbonate-fluorapatite, Virgin Valley, Nevada, USA, Miocene, radial view; (C,D) fluorapatite, Santa Fe River, Florida, USA, Neogene, radial view; (E,F) small euhedral apatite crystals on cell walls in carbonized wood, Yuba River, Nevada County, California, USA, Eocene, (E) oblique transverse view, (F) radial view. 


\section{Iron Minerals}

Woods mineralized with ferruginous compounds are not uncommon in the geologic record, not surprising because iron is the 4th most abundant element in the Earth's crust [31,32]. The iron minerals most likely to be associated with petrified wood are pyrite and marcasite $\left(\mathrm{FeS}_{2}\right)$, siderite $\left(\mathrm{FeCO}_{3}\right)$, hematite $\left(\mathrm{Fe}_{2} \mathrm{O}_{3}\right)$, goethite $(\alpha-\mathrm{FeO}(\mathrm{OH}))$ and $\left(\mathrm{FeO}(\mathrm{OH}) \cdot \mathrm{nH}_{2} \mathrm{O}\right)$. As noted later in this report, ferruginous fossil woods may contain manganese as a major constituent (Table 4).

Table 4. Woods mineralized with iron or iron/manganese.

\begin{tabular}{|c|c|c|c|}
\hline Mineralization & Age & Location & Reference \\
\hline Pyrite & Permian & Guadalajara, Spain & [33] \\
\hline Pyrite & Devonian & Hunsrück, Germany & {$[34,35]$} \\
\hline Pyrite & Devonian & Western France & {$[36,37]$} \\
\hline Pyrite & Paleocene & Colorado, USA & [38] \\
\hline Pyrite & Eocene & California, USA & This report \\
\hline Pyrite & Eocene & Kent, England & {$[39,40]$} \\
\hline Pyrite & Eocene & Louisiana, USA & [41] \\
\hline Marcasite & Miocene & Dresden, Germany & [42] \\
\hline Pyrite & Pliocene & Alméria, Spain & [43] \\
\hline Pyrite & Holocene & Georgia, USA & [44] \\
\hline Pyrite \& Hematite & Cretaceous & Hautrage, Belgium & [2] \\
\hline Iron oxide & Cretaceous & Oklahoma, USA & This report \\
\hline Iron oxide & Cretaceous & Montana, USA & This report \\
\hline Iron oxide & Pliocene & California, USA & This report \\
\hline Iron oxide & Quaternary & Siberia, USSR & [2] \\
\hline Goethite & unknown & unknown & {$[45]$} \\
\hline Goethite & unknown & Australia & [46] \\
\hline Goethite & Jurassic & Luków, Poland & [47] \\
\hline Goetite & Permian & Saiwan, Oman & [4] \\
\hline Goethite & Eocene & British Columbia, Canada & This report \\
\hline Goethite \& Hematite & Eocene & Cairo, Egypt & [48] \\
\hline Goethite \& Hematite & Pliocene & Dunrobba, Italy & [47] \\
\hline Goethite \& Lepidocrocite & Oligocene & Düsseldorf, Germany & [2] \\
\hline Goethite \& Lepidocrocite & Pleistocene & Ugchelen, The Netherlands & [2] \\
\hline Siderite & unknown & Siegen, Germany & [2] \\
\hline Siderite & unknown & Australia & [2] \\
\hline Siderite & Pennsylvanian & Illinois \& Indiana, USA & {$[49,50]$} \\
\hline Siderite & Paleocene & Alaska, USA & [51] \\
\hline Siderite & Paleogene & Alaska, USA & {$[52]$} \\
\hline Siderite & Neogene & Alaska, USA & [53] \\
\hline Siderite \& Hematite & unknown & Niederpleis, Germany & [2] \\
\hline Siderite \& Pyrite & Pleistocene & Oosterbeck, The Netherlands & [2] \\
\hline Hollandite \& limonite * & Jurassic & Transnubia, Hungary & [53] \\
\hline Mn-Fe oxide & Miocene & Nevada, USA & This report \\
\hline
\end{tabular}

${ }^{*}$ limonite is a mineraloid, not a true mineral. The name is commonly used to describe an unknown mixture of amorphous iron oxides and hydroxides having an approximate formula $\left(\mathrm{Fe}, \mathrm{O}, \mathrm{OH}, \mathrm{H}_{2} \mathrm{O}\right)$. The limonite name is included here because it was the term used in the original publication.

Identification of iron mineral in fossil wood is often difficult. Elemental analyses (e.g., XRF spectrometry, SEM/EDS) do not distinguish between the Fe sulfides marcasite and pyrite, or between the various Fe oxides and hydroxides. When well-developed crystals are present, SEM images may be useful for mineral identification, and XRD data can be used to make crystallography-based identification. Fe oxides and hydroxides are particularly difficult, because these minerals are often poorly crystallized or amorphous. As a result, XRD patterns for these minerals are of limited usefulness (Figure 8). Distinguishing between Fe oxides and hydroxides is also difficult, because conventional analytical methods of geochemical analysis do not measure hydrogen. At present, 
Mössbaur spectroscopy is potentially the most effective method for identification of iron minerals in fossil wood, but few specimens have been analyzed.

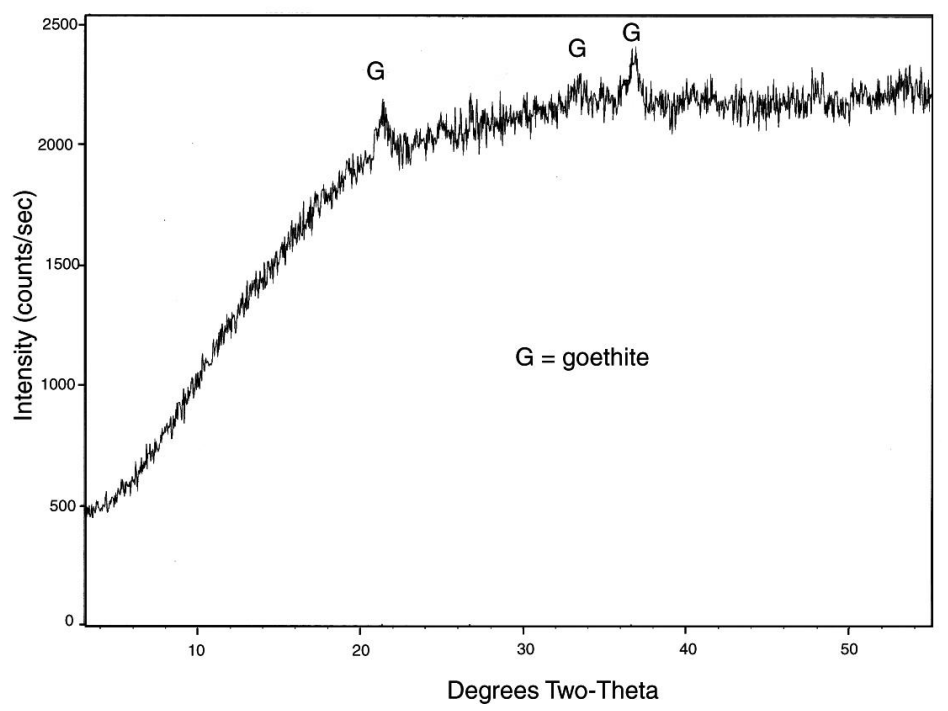

Figure 8. XRD pattern for iron-mineralized Eocene wood from Quinisco Lake, British Columbia, Canada. The generally-diffuse pattern contains weak peaks that indicate the presence of goethite, $\mathrm{FeO}(\mathrm{OH})$.

\subsection{Iron Oxides and Hydroxides}

Woods mineralized with iron oxides and hydroxides typically show poor preservation of wood structure (Figure 9), probably because these minerals typically form in the largest spaces available, where their relatively large crystal or particle sizes may inhibit accurate replication of cell structure. This mode of mineralization is very different from early stages of silicification, where silica forms bonds with hydroxyl groups of organic molecules within cell walls. This "organic templating" allows anatomical features to be preserved with high fidelity [54,55]. However, some Fe-oxide mineralized woods preserve recognizable cell structure (Figure 10).

Pyritization of plant and animals is a common form of fossilization, requiring weakly oxidizing to mildly reducing conditions and availability of dissolved sulfur and iron. Experimental studies have revealed that under favorable conditions, pyritization can occur at a very rapid rate [38]. This rapid fossilization may exceed the rate of organic degradation, which explains why delicate tissues can become pyritized $[34,40]$.

In plant tissues, pyrite textures include microcrystalline, framboidal, massive polycrystalline, and subhedral or euhedral forms [38]. In plant fossils from the Eocene London Clay, the highest fidelity of preservation occurs when pyrite occurs as microcrystalline precipitates on cell wall surfaces, with subsequent infilling of cell lumina with framboidal or polyhedral pyrite that prevents tissue compression during burial [40]. In laboratory experiments, pyrite precipitation is mediated by anaerobic bacterial-mediated decay of plant tissue, accompanied by pyrite precipitation on and within plant cell walls, cell lumina, and intracellular spaces [39]. Other possibilities exist. For example, the oldest known woody plant Armoricaphyton chateaupannense from Lower Devonian of France is preserved with carbonized cell walls and microcrystalline pyrite in cell lumen and as an accessory material in the walls [36]. At Macon, Georgia, USA, Holocene wood preserved in an anaerobic aquifer environment has been found to be mineralized with both silica and pyrite, with some adjacent silicate mineral grains in the matrix having been replaced by pyrite. The decaying wood is inferred to have served as a locus for sulfate reduction in a Fe-reducing groundwater system [44]. 

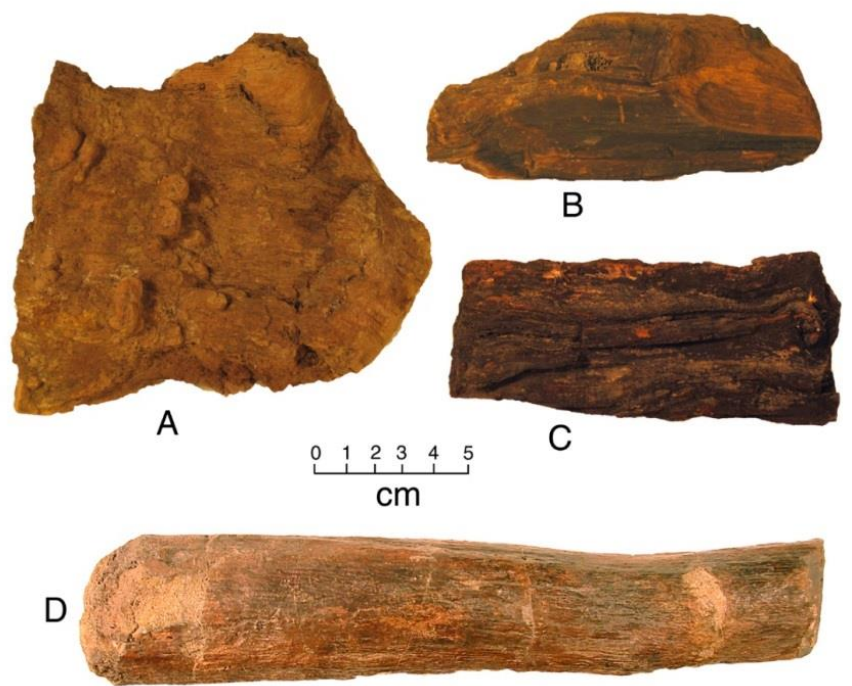

Figure 9. Iron oxide woods. (A) Pliocene, Burney, California, USA; (B) Eocene, Quinisco Lake, British Columbia, Canada; (C) Miocene, Fe-Mn oxides, Gooch Table, Virgin Valley, Nevada, USA; (D) Upper Cretaceous, Hell Creek Formation, eastern Montana, USA. This specimen preserves no cellular detail; it may be a limb cast.

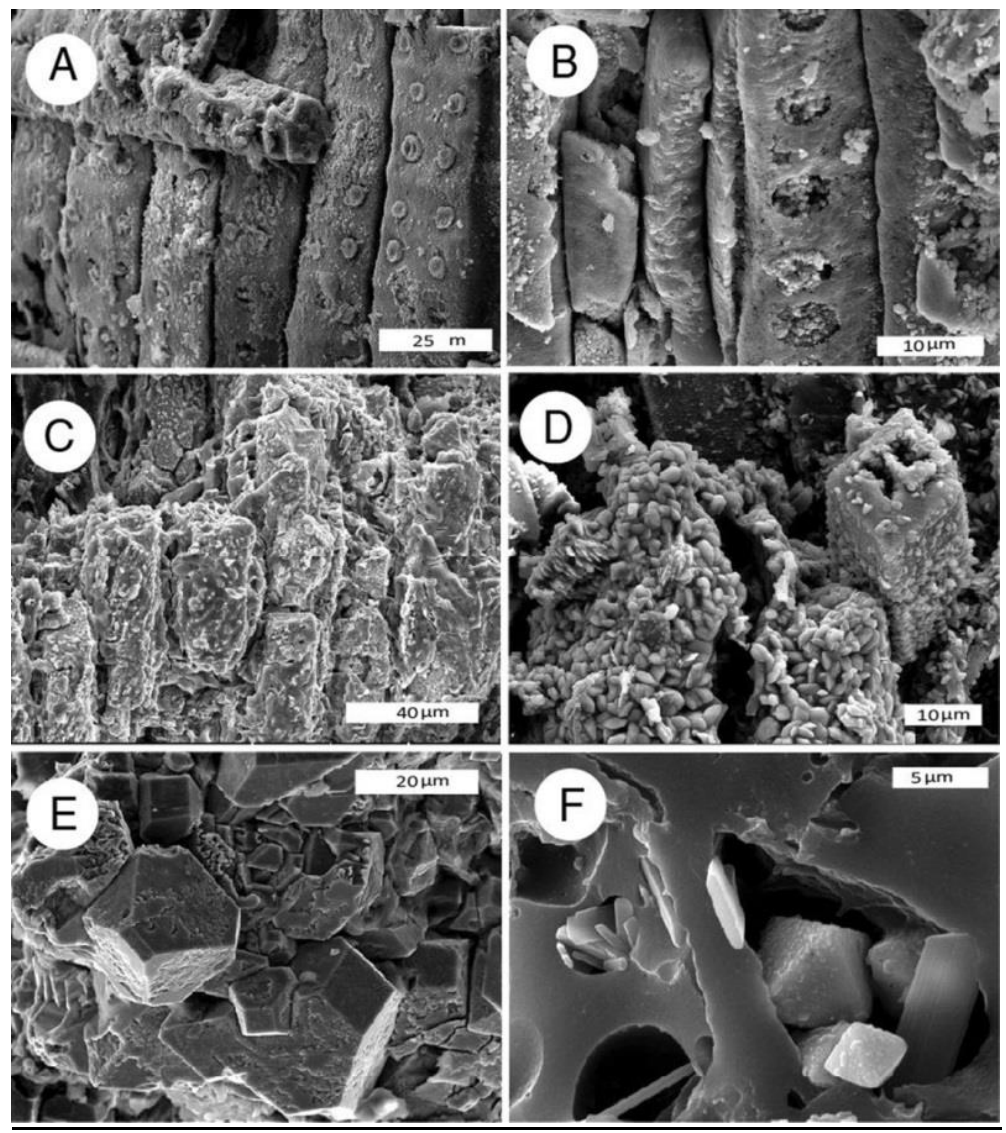

Figure 10. SEM images of iron-mineralized wood. (A,B) Iron oxide, Piocene, Burney, California, USA, oblique radial view; (C,D) Iron oxide, Lower Cretaceous, Antler, Oklahoma, USA; (C) radial view; (D) oblique transverse view shows hematite microcrystals replacing cell walls; (E,F) octahedral pyrite crystals in carbonized wood, oblique transverse view. Eocene, Yuba River, Nevada County, California, USA. 


\subsection{Iron Carbonate}

Siderite, $\mathrm{FeCO}_{3}$, is an iron mineral common in sedimentary environments, and it is associated with several fossilization processes. A well-known example is the type of ironstone concretion found in abundance at Pennsylvanian age sites at Mazon Creek, Illinois and Vigo Counties, Indiana, USA [42]. Foliage impressions are the most common fossils, but some nodules contain wood (Figure 11). The ironstone nodules consist of clay and siderite.

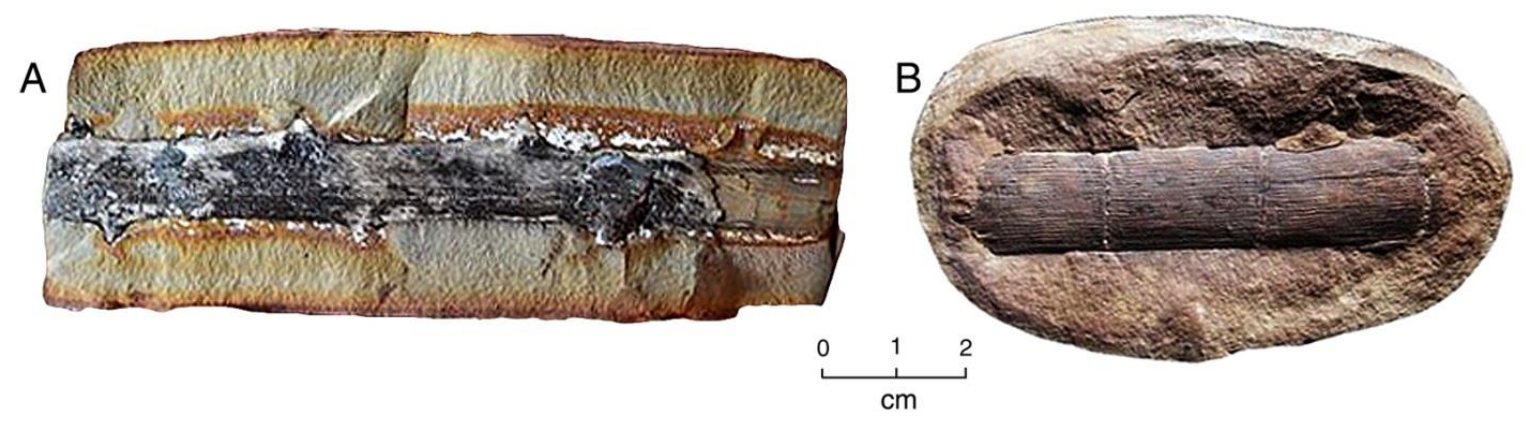

Figure 11. Sideritic "ironstone" nodules containing fossil wood, Pennsylvanian age, Mazon Creek, Braidwood, Illinois. (A) Unidentified woody twig; (B) Calamites.

Fossil wood mineralized with siderite has been reported from a variety of locations, including Siegen, Germany [2], and Australia [54]. Perhaps the most spectacular occurrences are found in Alaska, USA.

South Central Alaska: Logs and stumps are preserved in coal deposits in the early Paleocene Chikaloon Formation, south-central Alaska, USA [50]. The fossil wood commonly contains coalified organic matter, as well as inorganic minerals that may include quartz, ankerite (ferroan dolomite), and siderite. Mineral composition is related to stratigraphy: wood high in the $200 \mathrm{~m}$ section is dominantly mineralized with calcite and ankerite. At lower stratigraphic levels siderite is the primary constituent.

Southern Alaska: Siderite mineralized wood has been reported from Late Miocene coal beds exposed along the coast of Cook Inlet, near Homer, Alaska, but the mineralogy has not been described in detail $[51,52]$. Stumps and roots exposed by weathering of intertidal strata are very abundant (Figure 12). 

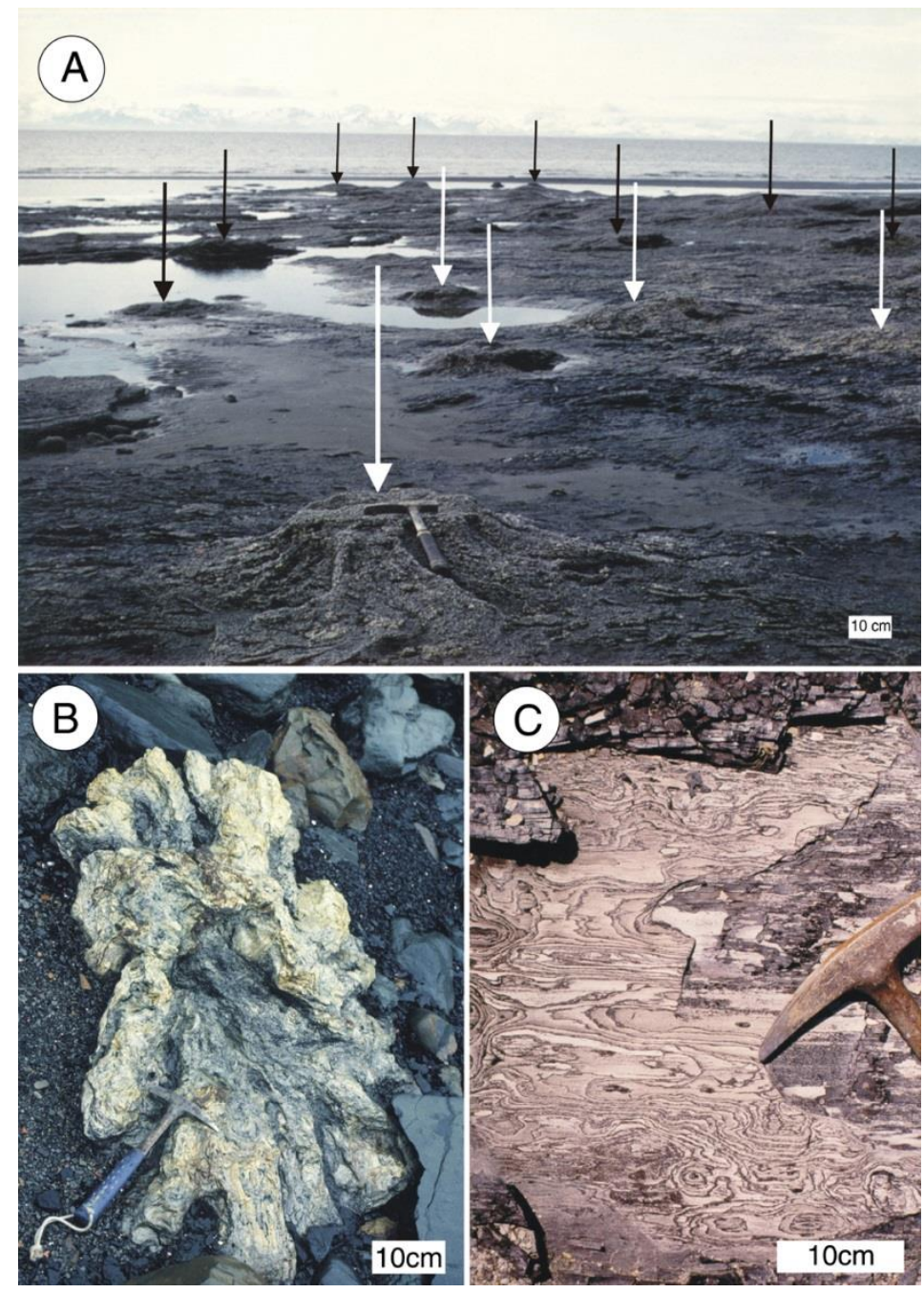

Figure 12. Late Miocene siderite mineralized wood Kenai Group near Homer, southern Alaska, USA. (A) Siderite mineralized stumps weathering from coal bed in intertidal zone north of Diamond Creek, Late Miocene Beluga Formation. Arrows mark individual stumps; (B) Siderite stump northwest of Michael Creek; (C) Close-up view of siderite-mineralized wood. Photos courtesy of Linda Reinike-Smith, used with permission.

\section{Manganese Oxide}

Manganese has not generally been reported as a major element in fossil wood, but in several instances fossil woods have been found to contain mixtures of iron and manganese oxides. One example is Jurassic wood from a manganese mine in Transnubia, Hungary. This wood is mineralized with hollandite, $\mathrm{Ba}\left(\mathrm{Mn}^{4+} \mathrm{Fe}^{3+}\right)_{8} \mathrm{O} 1_{6}$. At this locality, $\mathrm{Sr}$ is a partial replacement for Ba. The outer surface of the wood has an amorphous iron oxide ("limonite") crust. This mineralogy is inferred to represent hydrothermal processes within the ore zone [53].

A single specimen of manganese-bearing wood was collected by the author in 2004 from the Miocene Virgin Valley Formation in northwestern Nevada, USA. The specimen (Figure 9C) has poor anatomical preservation. The XRD pattern (Figure 13) shows quartz as the only crystalline component, suggesting that $\mathrm{Fe}$ and $\mathrm{Mn}$ are both present as amorphous materials. SEM images show the absence of well-formed crystals (Figure 14). SEM/EDS analysis shows the composition to be rich in iron and manganese oxide (Table 5). 


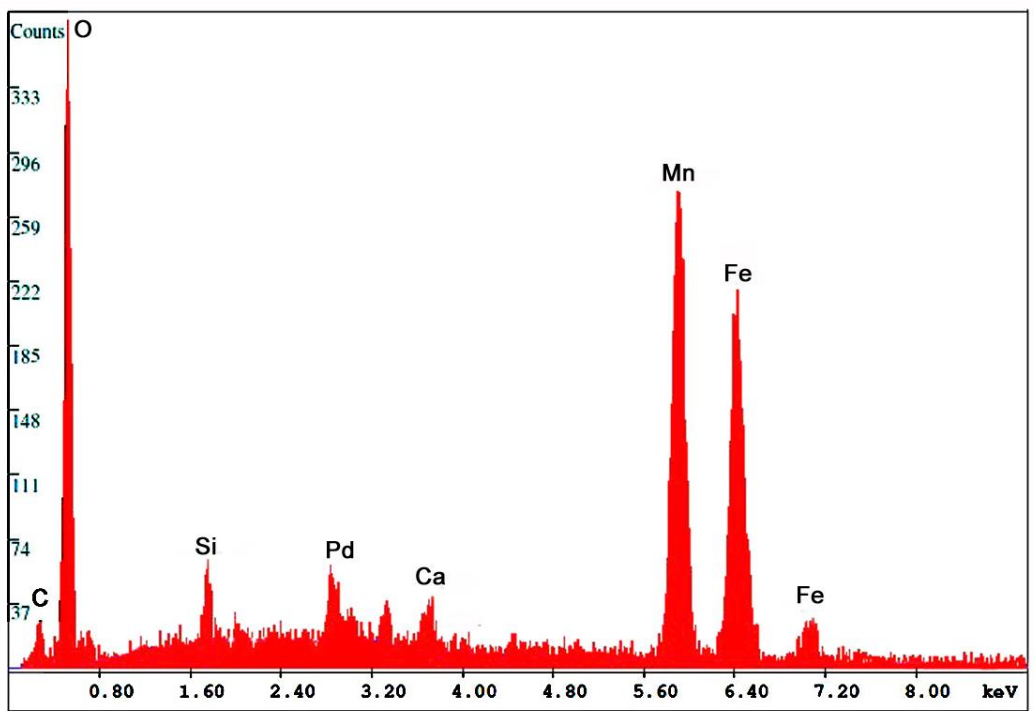

Figure 13. SEM/EDS spectrum for Fe-Mn oxide fossil wood from Virgin Valley, Nevada, USA.

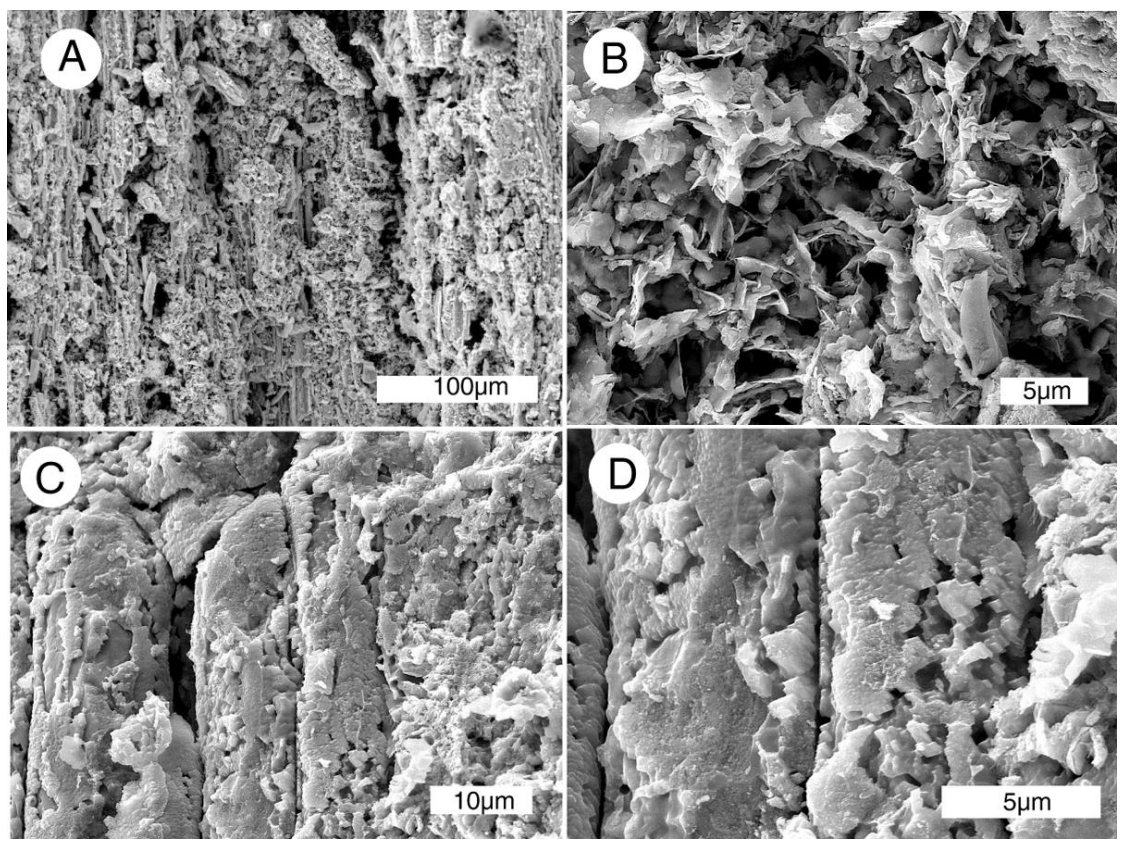

Figure 14. SEM radial views of Miocene wood mineralized with Mn-Fe, Virgin Valley, Nevada, USA, specimen in Figure 7C. (A,B) Tracheids mineralization showing flake-like morphology; (C,D) tracheids mineralized with blocky mineral particles.

Table 5. SEM/EDS data for Mn-Fe oxide fossil wood from Virgin Valley, Nevada, USA.

\begin{tabular}{ccccccc}
\hline & \multicolumn{2}{c}{ Analysis 1 } & \multicolumn{2}{c}{ Analysis 2 } & \multicolumn{2}{c}{ Mean } \\
\hline Element & Weight \% & Atomic \% & Weight \% & Atomic \% & Weight \% & Atomic \% \\
\hline $\mathrm{Si}$ & 1.9 & 2.5 & 2.4 & 2.9 & 2.2 & 2.7 \\
$\mathrm{Ca}$ & 1.7 & 1.5 & 1.7 & 1.5 & 1.7 & 1.5 \\
$\mathrm{Mn}$ & 45.9 & 23.3 & 40.4 & 25.1 & 43.2 & 25.2 \\
$\mathrm{Fe}$ & 25.0 & 15.1 & 31.3 & 19.1 & 28.2 & 17.1 \\
$\mathrm{O}$ & 24.4 & 51.6 & 24.2 & 51.5 & 24.3 & 51.5 \\
\hline
\end{tabular}




\section{Copper Minerals}

Copper minerals may produce spectacular colors in petrified. Among the best-known examples are Triassic specimens from the Nacimiento Mining District, Sandoval County, New Mexico, USA. Fossilization occurred in a fluvial deposit where buried logs and other plant material created reducing environments that caused mineral precipitation when copper-bearing solutions flowed through permeable channel sands. Logs with lengths of $10 \mathrm{~m}$ or more were replaced by primarily by chalcocite, with lesser abundances of bornite and covellite. Malachite, azurite and chryscolla occur in the sandstone matrix, formed by later oxidation. Small amounts of native silver occur along fractures in the carbonaceous material [56-59]. Some specimens contain iron pyrite, which appears to have been an early precipitate that preceded the appearance of copper minerals.

The host sandstone belongs to the Agua Zarca Member, Chinle Formation. Chinle Formation fossil woods at other sites (e.g., Petrified Forest National Park, Arizona, USA) are dominated by araucarian conifers, suggesting that the Nacimiento fossil wood is from a gymnosperm, but anatomical preservation is inadequate to allow accurate botanical identification.

Copper-mineralized wood occurs at several mines and prospects in the district, but the most prolific source of specimens is the Nacimiento Mine, near Castro, New Mexico, USA (Lat. $35.994^{\circ} \mathrm{N}$, Long. $106.897^{\circ} \mathrm{W}$, elevation $2277 \mathrm{~m}$ ). First worked as an underground mine in the $1880^{\prime} \mathrm{s}$, Nacimiento Mine was converted to an open pit in 1971 [56]. In 1980 nearly a million liters (250,000 gallons) of sulfuric acid were injected into the aquifer to extract $\mathrm{Cu}$ in situ [60]. A four-year remediation program was instituted in 2009, pumping contaminated water to a surface treatment plant. The mine is presently abandoned, and the open pit being occupied by a small lake (Figure 15), but specimens can be collected from the mine dumps bordering the lake. These specimens predate underground acidification, and represent original ore mineralization and subsequent surface weathering.

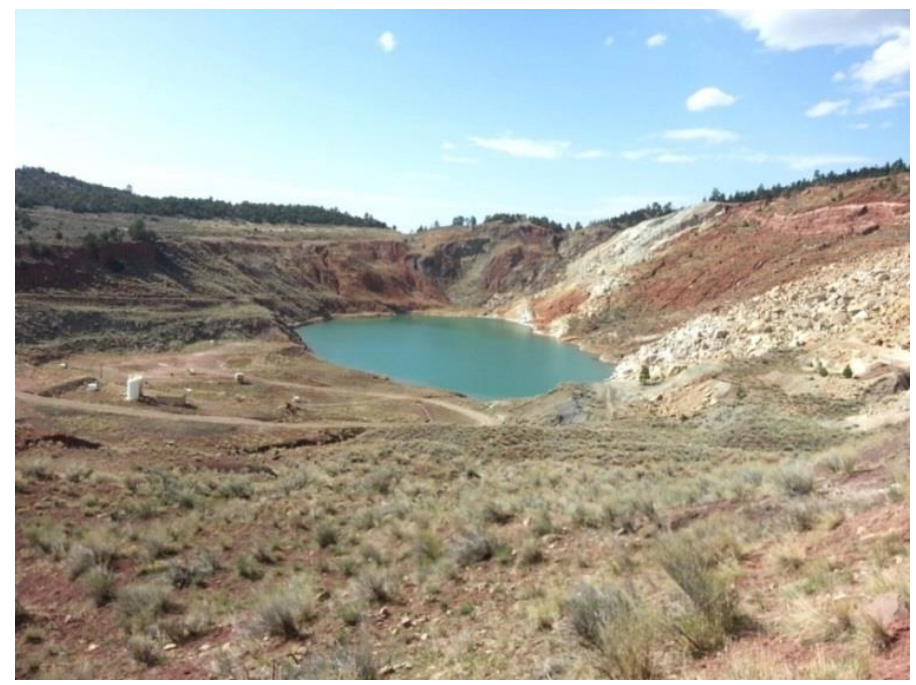

Figure 15. Nacimiento Mine site, near Cuba, New Mexico, USA. 2016 photo. Fossil wood can be collected from mine dumps bordering the water-filled open pit mine.

During the era of active mining, specimens were reported to have bornite replacement of cell walls, with chalcocite filling cell lumina [57,58]. Specimens presently available for study (Figure 16) come from mine waste piles, and do not typically show that cellular mineralization. In many specimens, wood has been completely replaced by copper minerals, chalcocite and chalcopyrite being the most abundant phases. Carbonized wood commonly shows relict wood grain but cellular structure is poorly preserved. In some specimens, cell walls are carbonized, with minerals (particularly marcasite) precipitated within cell lumen. Other specimens that show relict wood grain texture may be mineralized with microcrystalline hematite, with euhedral aragonite as a minor constituent (Figure 17). In wood that 
has been replaced by chalcocite, the rather featureless texture has been interpreted as evidence of deformation or recrystallization of the original mineral phase [57].

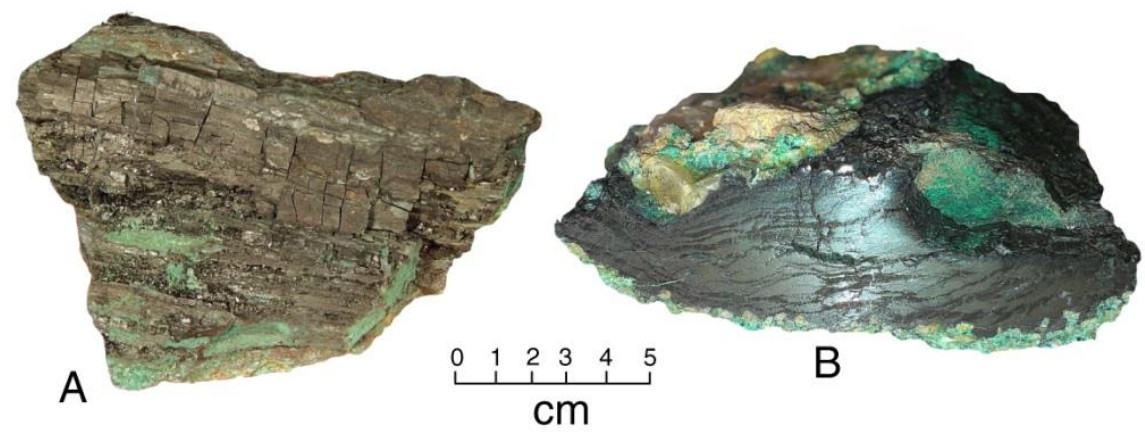

Figure 16. Triassic wood from the Nacimienento Mine, New Mexico, USA. (A) Specimen shows carbonized wood in sandstone matrix stained green from malachite; (B) Polished sawn surface. Wood has been replaced by primarily by chalcocite, and is enclosed within malachite-bearing sandstone.

Malachite, azurite are alteration products that are visibly abundant in sandstone adjacent to the fossils wood, but their accurate detection in EDS spectra is impossible because the presence of relict carbon in the fossil wood obscures the possible presence of these carbonate minerals. Likewise, chryscolla $\left(\mathrm{CuO} \cdot \mathrm{SiO}_{2} \cdot 2 \mathrm{H}_{2} \mathrm{O}\right)$ does not yield a recognizable EDS spectrum because of the high silica content of the sandstone matrix.

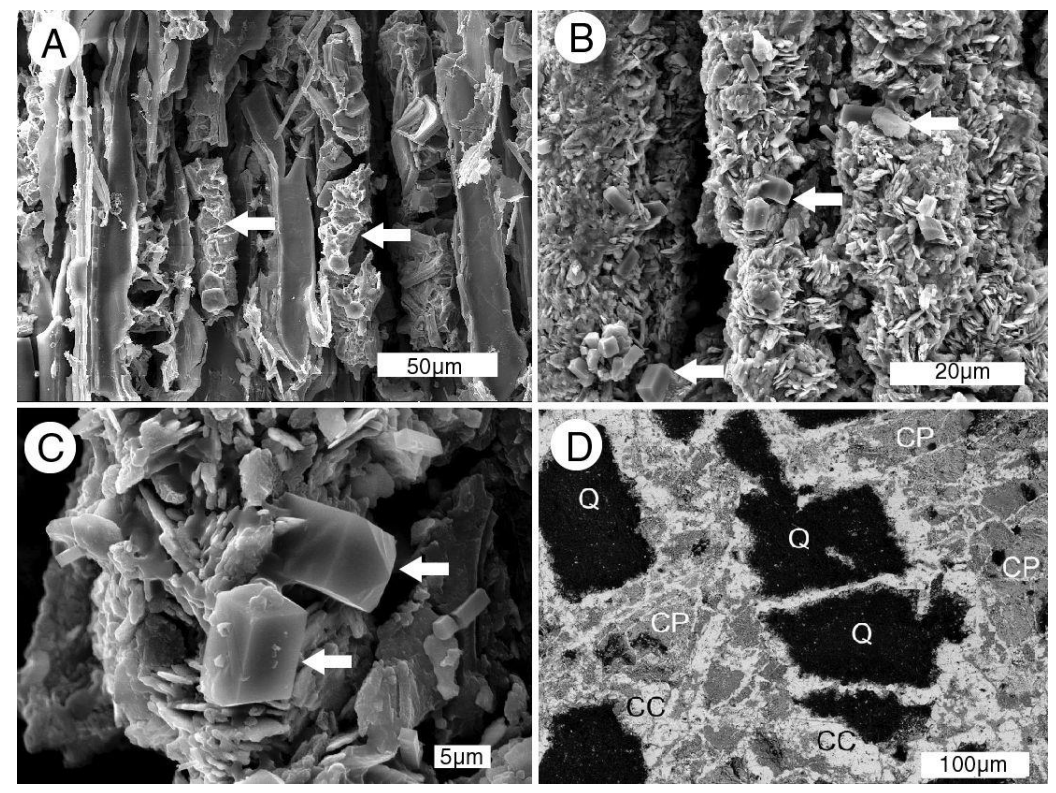

Figure 17. SEM images of iron mineralized wood from the Naciemento Mine. (A) Carbonized cell walls and cell lumina contain marcasite (arrows); (B) cells mineralized with tabular crystals of hematite, with small prismatic aragonite crystals (arrows); (C) high magnification view showing bipyramidal orthorhombic aragonite crystals on hematite (arrows); (D) back-scattered electron image of cut surface of wood replaced by minerals. $Q$ = quartz sand grains from the fossil matrix are enclosed within a complex matrix of chalcopyrite (CP) and chalcocite (CC).

Fossil wood from the Nacimiento Mine is similar in geologic origin to Early Permian wood that occurs in copper mines in Oklahoma (Figure 18). At these mines, carbonized wood was primarily mineralized with chalcocite, with minor chalcopyrite, calcanthite, and native copper. Supergene alteration produced malachite and azurite $[61,62]$. 


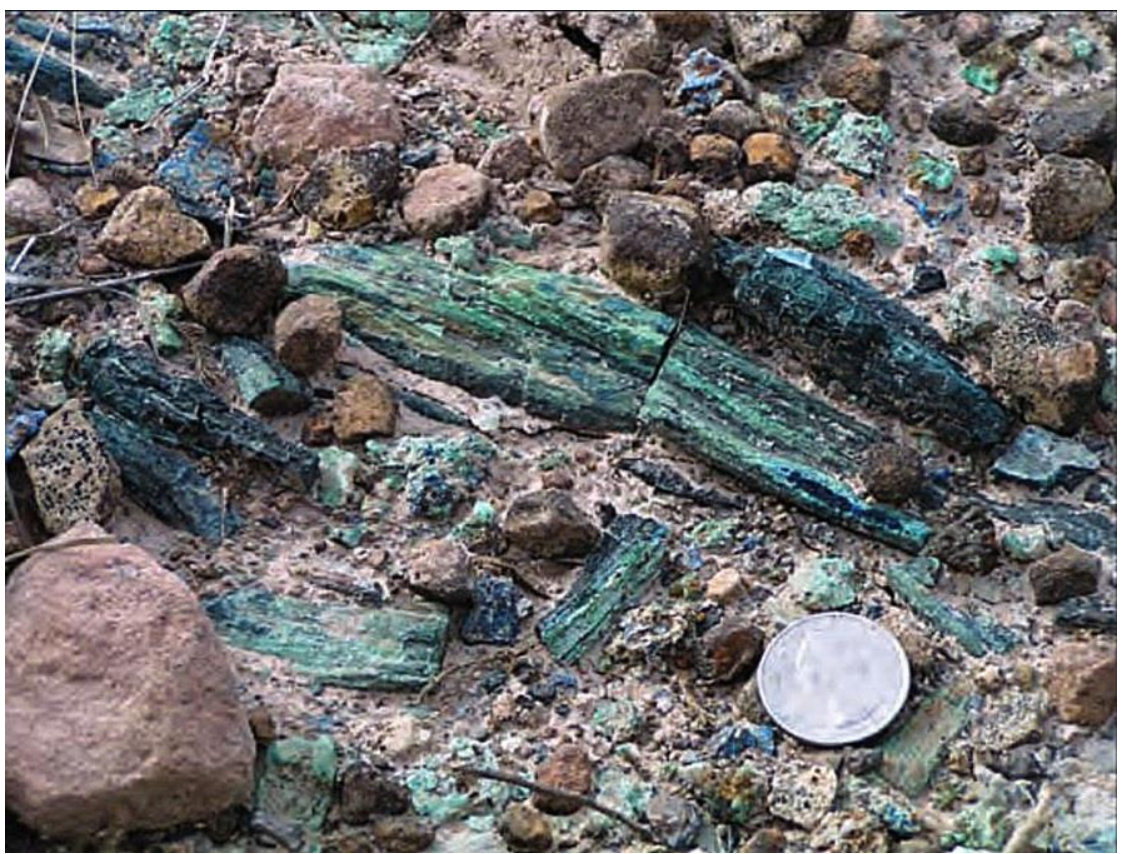

Figure 18. Copper-mineralized wood from Lower Permian Matfield Shale, Pawnee Oklahoma USA. Oklahoma Geological Survey photo by N.H. Suneson. Diameter of coin is $25 \mathrm{~mm}$.

Silicified wood containing copper minerals was discovered in 2012 in the Black Sea region, when a petrified log was excavated by gold prospectors near the town of Zile, in Tolkat Province, Turkey (Figure 19). This occurrence is described in detail because this it has not previously been reported in scientific literature. The only published account of the discovery is a brief article in a Turkish newspaper [63]. Specimens were collected in 2013 by commercial collectors, who used a sledgehammer to break fragments from the log. These specimens were marketed as "colla wood" because of the presumed abundance of chryscolla, but microscopic examination reveals that this mineral is only a minor constituent; the blue and green colors are mostly due to malachite and azurite (Figures 20 and 21). The regional setting suggests that the wood is of Miocene age [64]. The finders hoped to excavate for additional material, but they were unable to obtain collecting permits; the international marketing of the original specimens generated much controversy in Turkey because of public concern regarding the export of fossil specimens. Further collecting is unlikely, and the scarcity of "colla wood" has caused specimens to be highly prized by collectors.
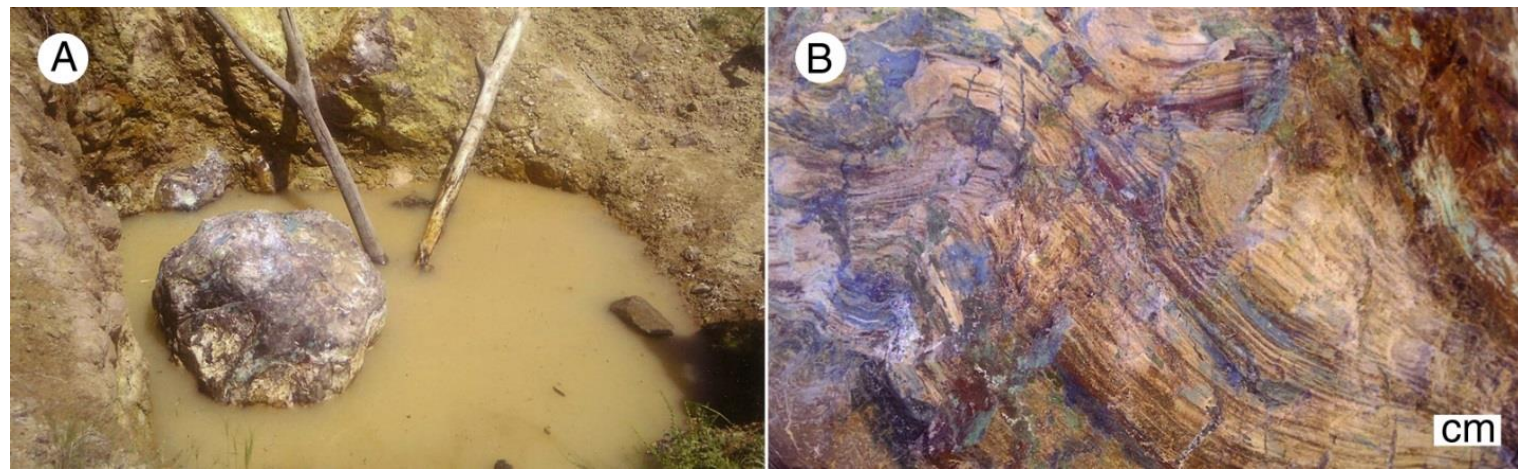

Figure 19. Copper-mineralized silicified log near Zile, Turkey, photographed at the discovery site in 2013. (A) Most specimens sold for export were obtained from this $\log$ (B) close-up view of the surface. Photos courtesy of Ziledin Haberler, used with permission. 

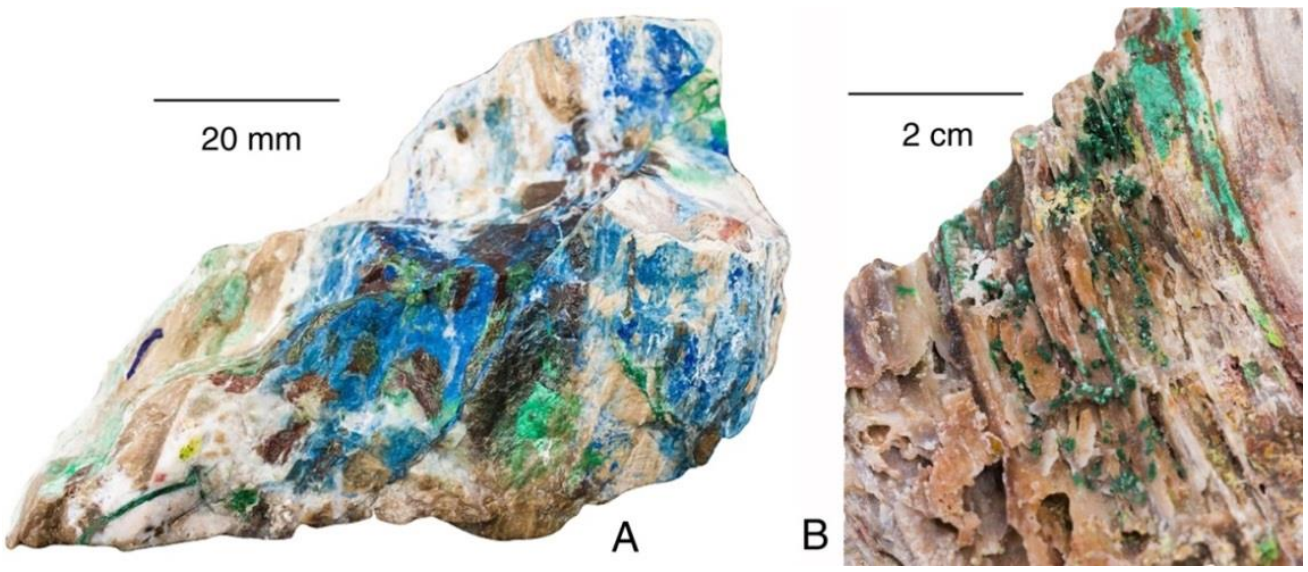

Figure 20. "Colla wood" primarily owes its bright colors to blue azurite (A) and green malachite (B).

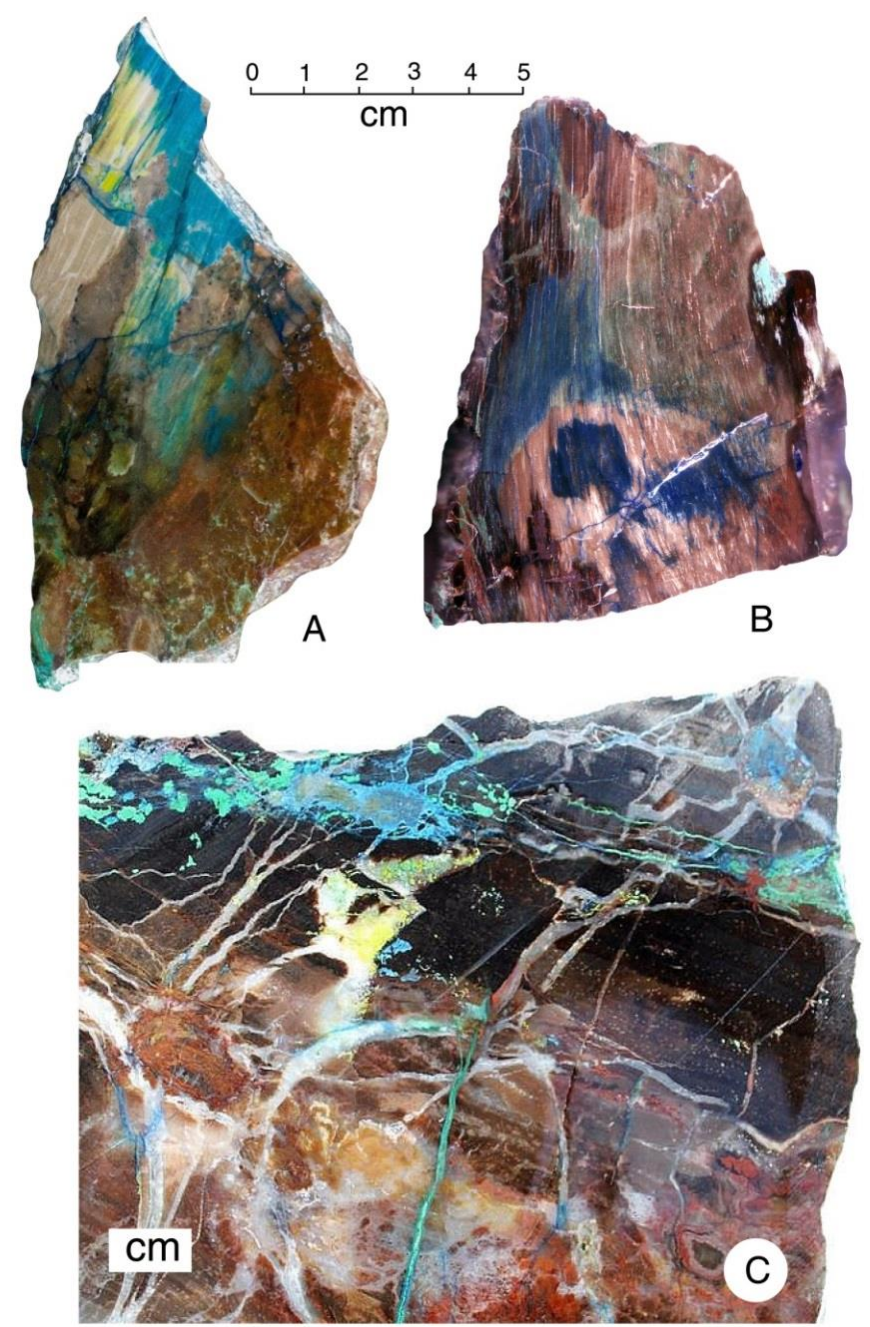

Figure 21. Color patterns are evidence of a complex mineralization sequence, where mineral-bearing solutions penetrated partially silicified wood to form diffuse color zones $(\mathbf{A}, \mathbf{B})$, and along fractures to produce geometric shapes $(\mathbf{C})$.

From its first discovery, "colla wood" has been asserted to be opalized. However, X-ray diffraction patterns (Figure 22) show that silica is present as microcrystalline silica (chalcedony), not opal. 
Vivid color patterns are evidence of complex mineralogy. Optical microscopy (Figure 23) reveals a petrifaction sequence in which the wood was partially silicified, but still permeable to mineral-bearing groundwater. This interpretation is based on diffuse color patterns, a common feature (Figure 23A-C).

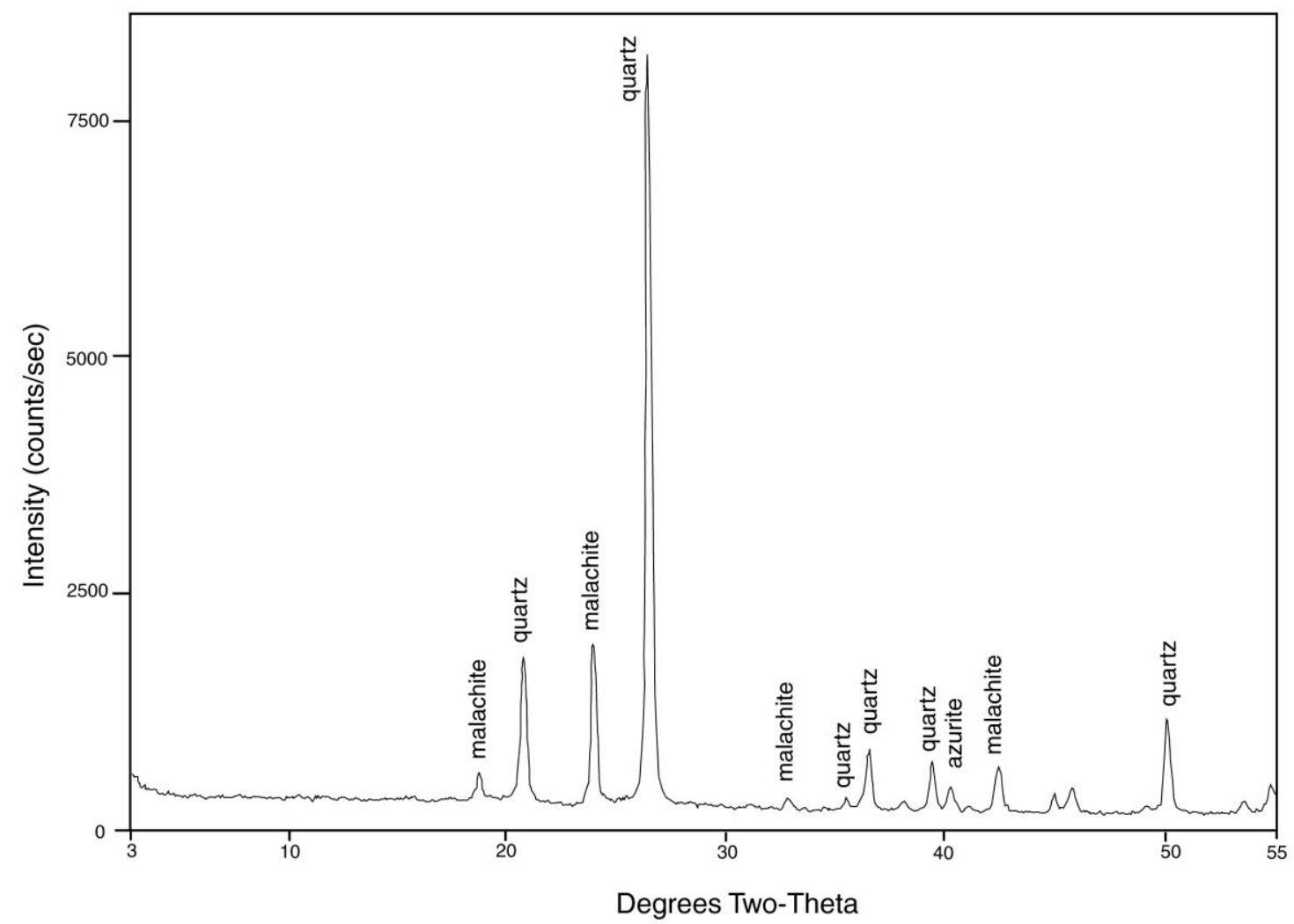

Figure 22. XRD pattern of "colla wood" from Turkey. Cu K-alpha radiation.

The mineral composition of the "colla wood" is highly variable, within a single small specimen (Figure 23D). These assemblages are evidence of multiple episodes of mineral precipitation, where the chemical composition of pore water changed between successive episodes, or by changes in $\mathrm{pH}$ or Eh that caused different minerals to precipitate. For example, the gradual loss of organic matter may have been accompanied by a change in redox potential. In addition to color patterns caused by diffusion effects, silicification produced a brittle texture; fractures are bordered by bright coatings of copper minerals where fluids migrated along these openings (Figure 23E). In a later episode, chalcedony was precipitated as fracture-filling (Figure 23F).

Reflected light optical microscopy of polished slabs shows the distribution of individual mineral phases (Figure 24). These mineral compositions were confirmed by SEM/EDS elemental analysis. These results are in marked contrast to the labelling of specimens obtained by collectors. The most abundant mineral is chalcedony, not opal. Bright colored minerals include azurite and malachite (polymorphs of $\mathrm{CaCO}_{3}$ ); despite the popular name "colla wood", chryscolla (hydrated Cu silicate) is a very minor component. A reddish metallic mineral assumed to be cuprite $\left(\mathrm{Cu}_{2} \mathrm{O}\right)$ or chalcocite $\left(\mathrm{Cu}_{2} \mathrm{~S}\right)$ turns out to be hematite $\left(\mathrm{Fe}_{2} \mathrm{O}_{3}\right)$. Malachite and cuprite commonly occur as discrete entities, rather than as intergrading minerals (Figure 24A,B). 

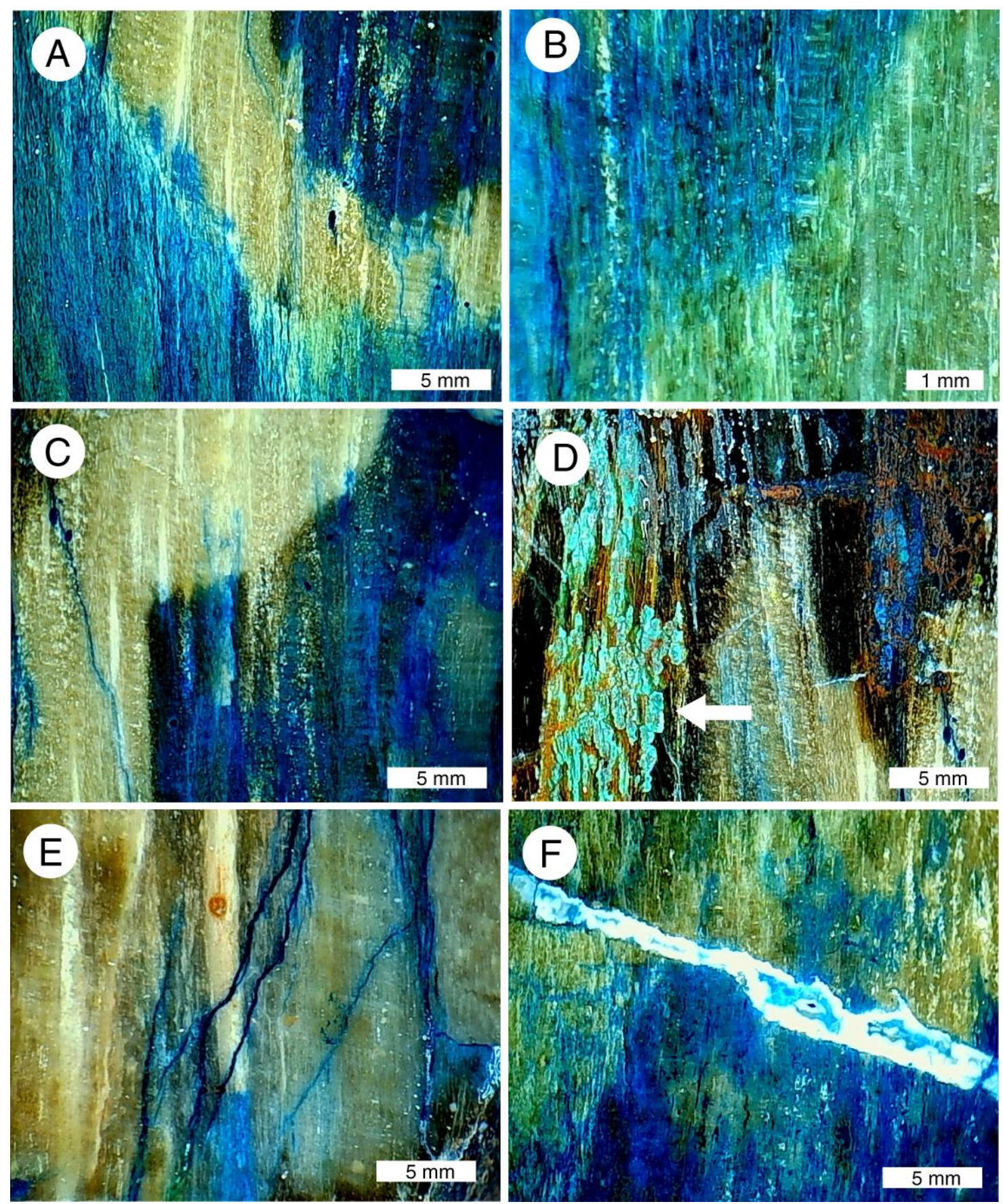

Figure 23. Low-power magnified views of "colla wood". (A-C) Images show vivid color patterns caused by diffuse infiltration of copper minerals into silicified tissue; (D) chryscolla, marked with arrow, is a minor constituent; most coloration is due to malachite (green) and azurite (blue); (E) azurite was deposited by fluids moving through fractures in silicified wood; (F) copper-stained chalcedony fills fracture that cross-cuts wood grain. 


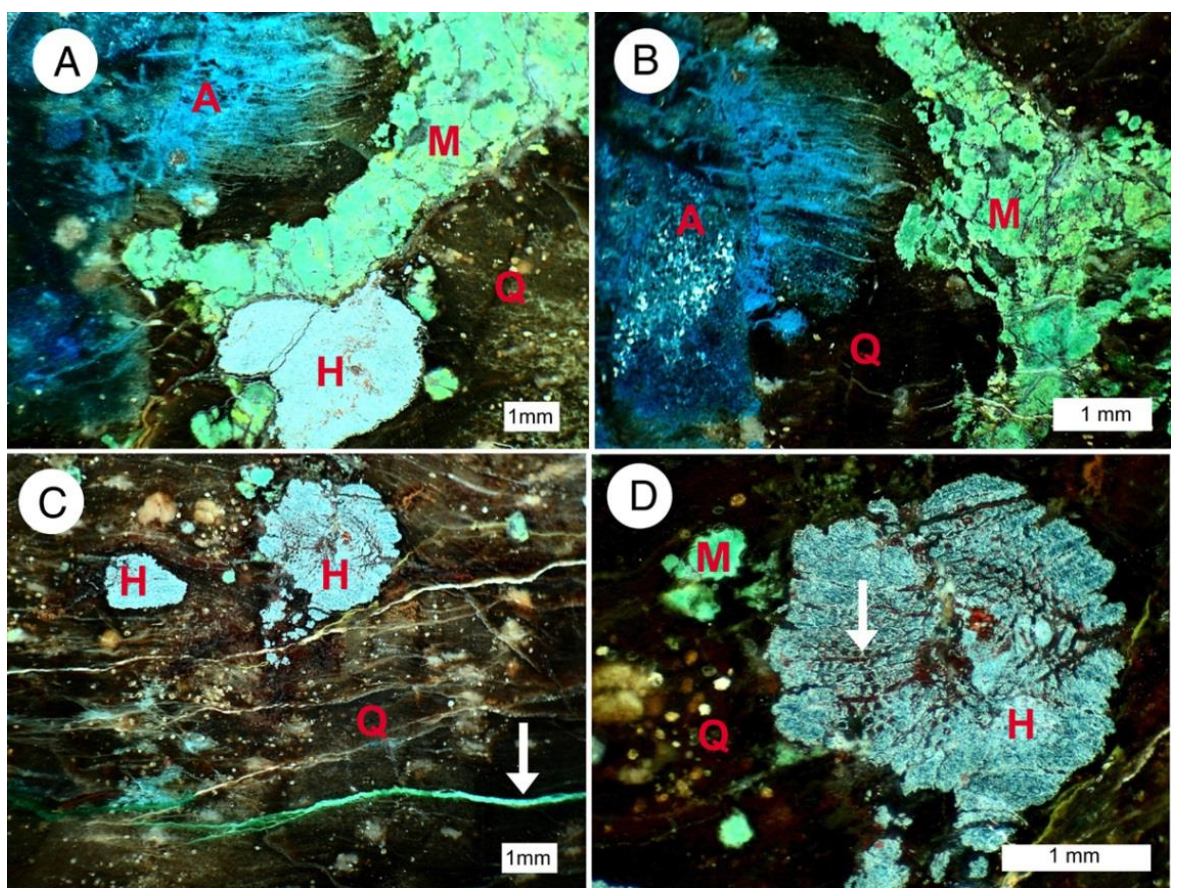

Figure 24. Reflected light microscope images. Abbreviations: $\mathrm{A}=$ azurite; $\mathrm{M}=$ malachite, $\mathrm{H}=$ hematite, $\mathrm{Q}=$ quartz (chalcedony). (A,B) Azurite has diffused along wood grain direction; (C) arrow marks malachite veinlet; (D) hematite sometimes shows rudimentary preservation of wood cell structure (arrow).

A bright yellow mineral has been interpreted to be sulfur, but SEM/EDS analyses (Table 4) reveal that this material is a copper, vanadium oxide This mineral infiltrates fractures and forms alteration rims on some brecciated wood fragments (Figure 25A)., and locally fills many cell lumina (Figure 25B).

SEM/EDS spectra data (Table 6) show that the yellow mineral has a $\mathrm{Cu}: \mathrm{V}$ ration of $\sim 3: 2$, confirming the identity as volbrothite, $\mathrm{Cu}_{3}\left(\mathrm{~V}_{2} \mathrm{O}_{7}\right) \mathrm{OH}_{2} \cdot 2 \mathrm{H}_{2} \mathrm{O}$. Only two other cupper-vanadium oxide minerals have this $\mathrm{Cu}: \mathrm{V}$ ratio are pseuodolyonsite, $\mathrm{Cu}_{3}\left(\mathrm{VO}_{4}\right)_{2}$, and borisenkoite $\mathrm{Cu}_{3}\left[(\mathrm{~V}, \mathrm{As}) \mathrm{O}_{4}\right]_{2}$. Both minerals are dark red to black in color. In addition, SEM/EDS spectra lack the As peak that is characteristic of borisenkoite.
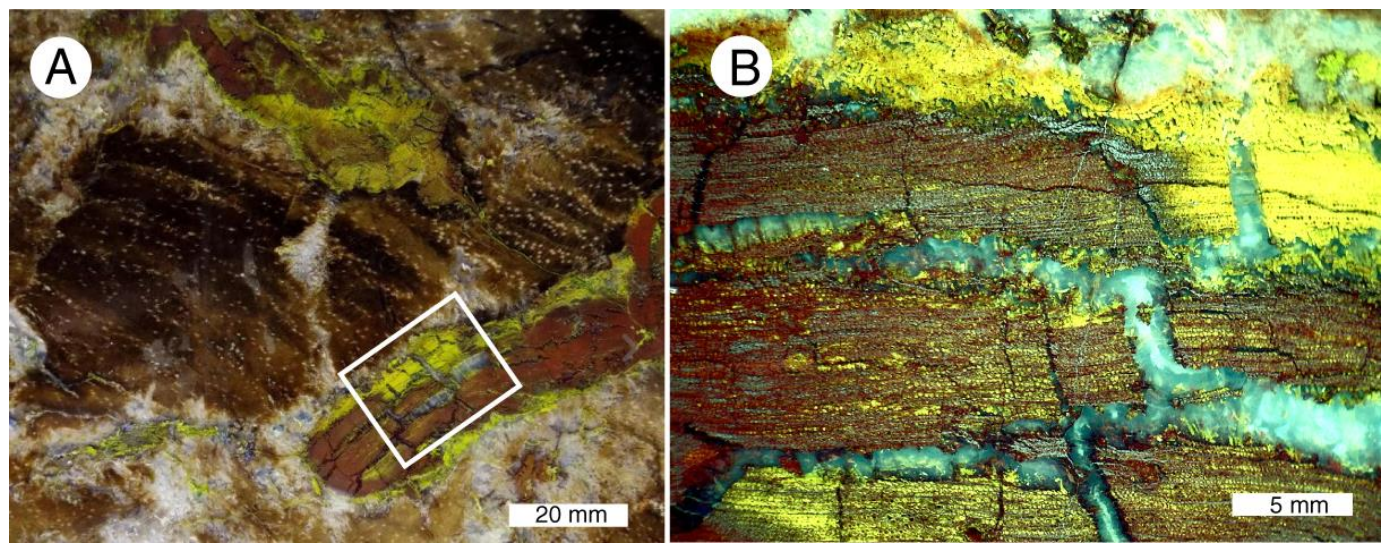

Figure 25. Volbrothite in "colla wood". (A) This yellow mineral infiltrates marginal areas of brecciated silicified wood fragments, and fills the lumina of many cells. (B) Light-colored areas are chalcedonyfilled fractures. 
Table 6. SEM/EDS analysis of yellow mineral in colla wood.

\begin{tabular}{ccccccccc}
\hline \multirow{2}{*}{ Element } & \multicolumn{2}{c}{ Analysis 1 } & \multicolumn{2}{c}{ Analysis 2 } & \multicolumn{2}{c}{ Analysis 3 } & \multicolumn{2}{c}{ Average } \\
\cline { 2 - 8 } & Weight \% & Atomic \% & Weight \% & Atomic \% & Weight \% & Atomic \% & Weight \% & Atomic \% \\
\hline $\mathrm{O}$ & 20.4 & 48.1 & 20.9 & 48.7 & 27.2 & 55.6 & 22.8 & 50.8 \\
$\mathrm{Al}$ & 0.20 & 0.28 & 0.34 & 0.47 & 0.64 & 0.78 & 0.39 & 0.51 \\
$\mathrm{Si}$ & 0.82 & 1.09 & 1.07 & 1.42 & 3.61 & 4.21 & 2.11 & 2.24 \\
$\mathrm{As}$ & 1.13 & 0.57 & 1.12 & 0.56 & 1.39 & 0.61 & 1.21 & 0.58 \\
$\mathrm{Ti}$ & 2.03 & 1.59 & 1.96 & 1.53 & 8.48 & 5.80 & 4.16 & 2.97 \\
$\mathrm{Fe}$ & 2.90 & 1.95 & 2.06 & 1.37 & 0.93 & 0.54 & 1.96 & 1.29 \\
$\mathrm{Cu}$ & 48.8 & 29.9 & 49.3 & 28.3 & 37.0 & 19.1 & 45.0 & 25.8 \\
$\mathrm{~V}$ & 23.7 & 17.5 & 24.2 & 17.7 & 20.8 & 13.4 & 22.9 & 18.4 \\
$\mathrm{Cu}: \mathrm{V}$ & & $\mathbf{3 . 4 : 2}$ & & $\mathbf{3 . 2 : 2}$ & & $\mathbf{2 . 8 : 2}$ & & $\mathbf{2 . 8 : 2}$ \\
\hline
\end{tabular}

\section{Fluorite}

One of the most unusual examples of non-silica wood mineralization occurs at Chemnitz, Germany, the site of a Lower Permian petrified forest. Fossilization resulted when a volcanic eruption entombed a plant assemblage that includes tree ferns, arboreal sphenophytes, gymnosperms, and epiphytic plans [65-69]. Most specimens are mineralized with quartz and moganite (chalcedony), with minor amounts of iron oxide. However, in one particular volcanic ash bed, specimens also contain crystalline fluorite (Figure 26). This mineralization has been interpreted as evidence of a multi-stage process when fluorite-bearing fluids infiltrated along cracks and decayed areas of wood that had previously been partially mineralized with amorphous silica [55]. Cathodoluminescence microscopy (CL) has proven to be a valuable method for studying the distribution of fluorite in Chemnitz wood [65-68]. However, the "fluorite phenomenon" in Chemnitz fossils is not yet clearly understood. In some samples, a single tracheid may be mineralized with fluorite, while adjacent tracheids contain quartz. In other samples some areas are fully replaced by fluorite, or an intermixture of fluorite and quartz. More investigations are needed to better understand this mode of mineralization.
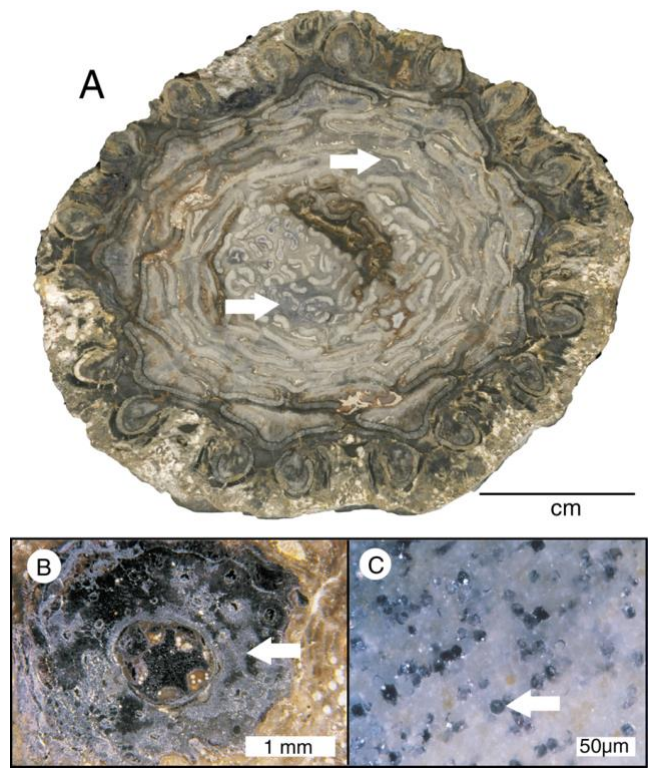

Figure 26. Silicified wood from Chemnitz, Germany, containing fluorite (marked with arrows). (A) Psaronius infarctus, with patchy fluorite; (B) climber Ankyropteris brongniartii. Fluorite is dark gray; (C) silicified gymnosperm wood with fluorite filling individual tracheids. Photos courtesy of Ronny Rößler, used with permission.

At Chemnitz, woods containing fluorite are only preserved in a single pyroclastic layer in the tuff succession. Within this layer, there is a gradual transition in the quartz-mineralized wood where 
fluorite grades from being a minor constituent to a dominant component [66]. Fluorite is commonly distributed along cell walls, and in zones related to differing anatomical regions (Figure 27).

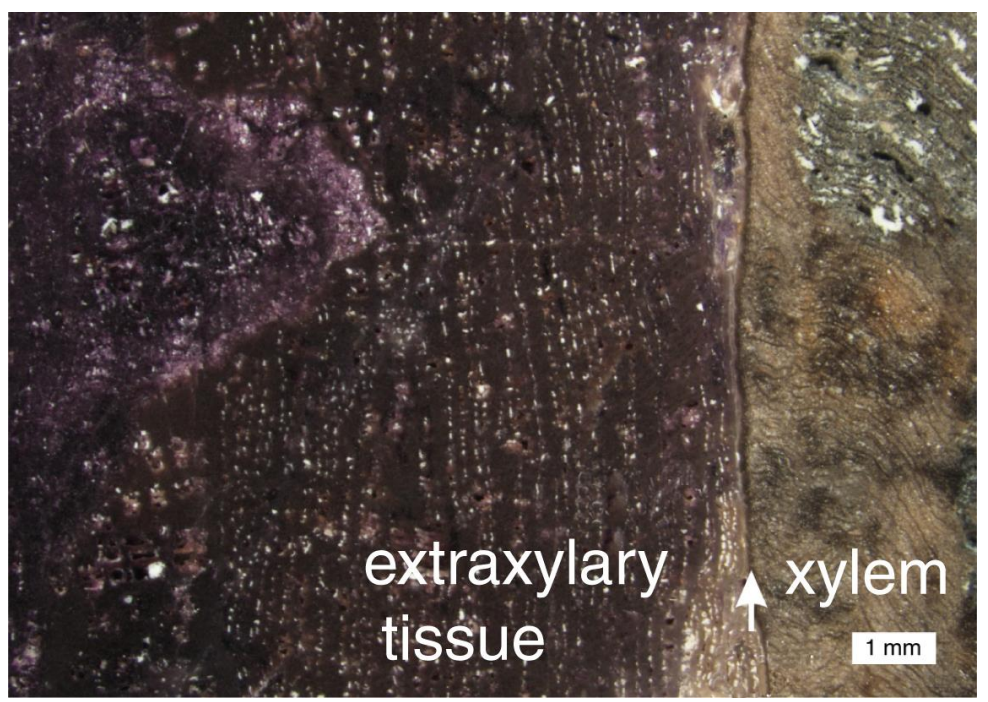

Figure 27. In many specimens of Chemitz wood that contain fluorite, the mineral occurs in irregular patchy zones, but in this sample, the main trunk tissue (xylem) is silicified, and fluorite is restricted to the outermost stem tissues (extraxylary tissues). Arrow marks cambium layer. Photo courtesy of Ronny Rößler, used with permission.

\section{Barite}

Unusual fossil plant preservation occurs at the Steinhardt quarry at Bad Doberheim, Germany. Abundant sandstone concretions in the Oligocene Unter Meersand Formation contain barite-mineralized wood and conifer cones (Figure 28). This mineralization has been interpreted as having resulted from an oxidizing environment where hydrogen sulfide from decaying organic matter reacted with dissolved Ba in groundwater [70,71].
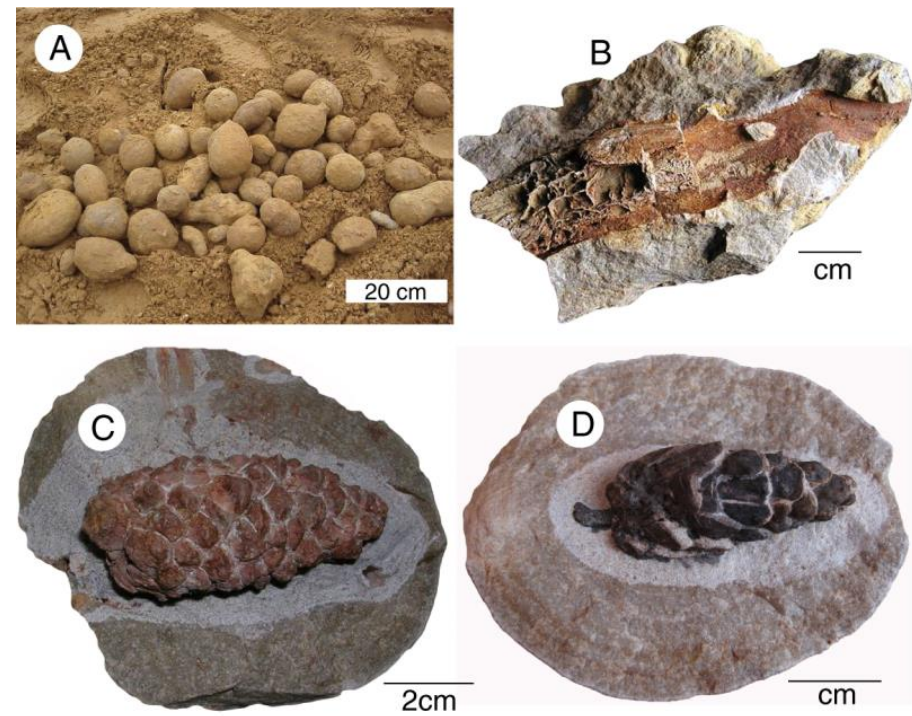

Figure 28. Fossiliferous nodules from Steinhardt Quarry. (A) Sandstone concretions gathered from quarry strata; (B) barite replacement of wood; (C,D) barite replacement of conifer cones. 


\section{Volkonskoite: Chromian Smectite Clay}

In terms of mineral composition, one of the rarest fossil woods comes from Permian sedimentary rocks in the western foothills of the southern Ural Mountains in western Russia (Figure 29). At a locality near Mount Efmiatskaya, wood has been replaced with volkonskoite, a hydrous calcium chromium magnesium iron hydroxyl-aluminosilicate, which has a generalized composition of $\mathrm{Ca}_{0.3}\left(\mathrm{Cr}^{+3} \mathrm{Fe}^{+3}\right)_{2}(\mathrm{Si}, \mathrm{Al})_{4} \mathrm{O}_{10} \cdot 2 \mathrm{H}_{2} \mathrm{O}[72,73]$. Anatomical preservation is generally very poor, but a cellular structure is evident in a few specimens. The mineralization sequence has not been studied, but volkonskoite is known to form as an alteration of serpentine-rich bedrock. The green color is caused by the high chromium content, which can exceed 20 Weight \% Cr [73].
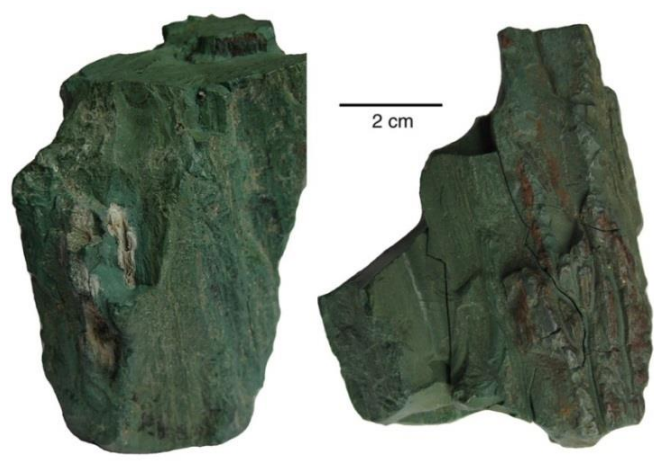

Figure 29. Permian wood replaced by volkoenskite, from Ural Mountains, western Russia. Photos courtesy of Mike Viney, used with permission.

\section{Natrolite and Calcite}

Neogene tuff beds on the lower slope of Mount Elgon, an extinct volcano located on the Kenya-Uganda border [74], preserve a diverse array of fossil wood [75-78]. The age is probably Lower Miocene [78]. In some specimens, wood has been replaced by natrolite (a sodium zeolite) and calcite. Zeolites, particularly natrolite, are abundant in Mt. Elgon volcanic flows and agglomerates, evidence of magma that contained high water content. Calcite commonly occurs in association with the natrolite, the carbonate mineral having formed both as a primary mineral and as a weathering product $[79,80]$. The zeolite-rich wood has not been studied in detail, but fossilization commonly results from mineralization of outer-most tissues, with slender natrolite crystals radiating into interior spaces (Figure 30). In other specimens, wood is completely replaced by interlocking crystals of stilbite and calcite (Figure 31).

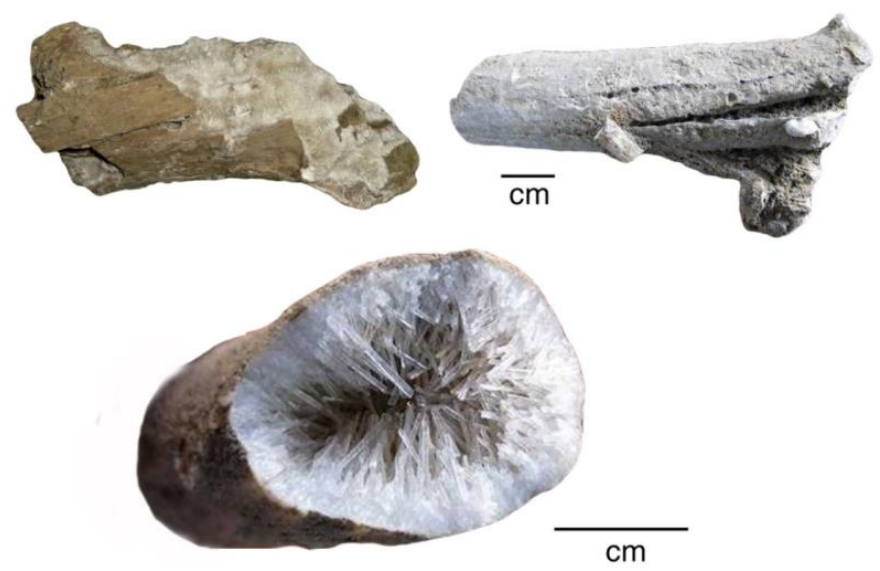

Figure 30. Wood mineralized with calcite and natrolite, Mount Elgon, Uganda, Miocene age. Photos courtesy of Mike Viney, used with permission. 

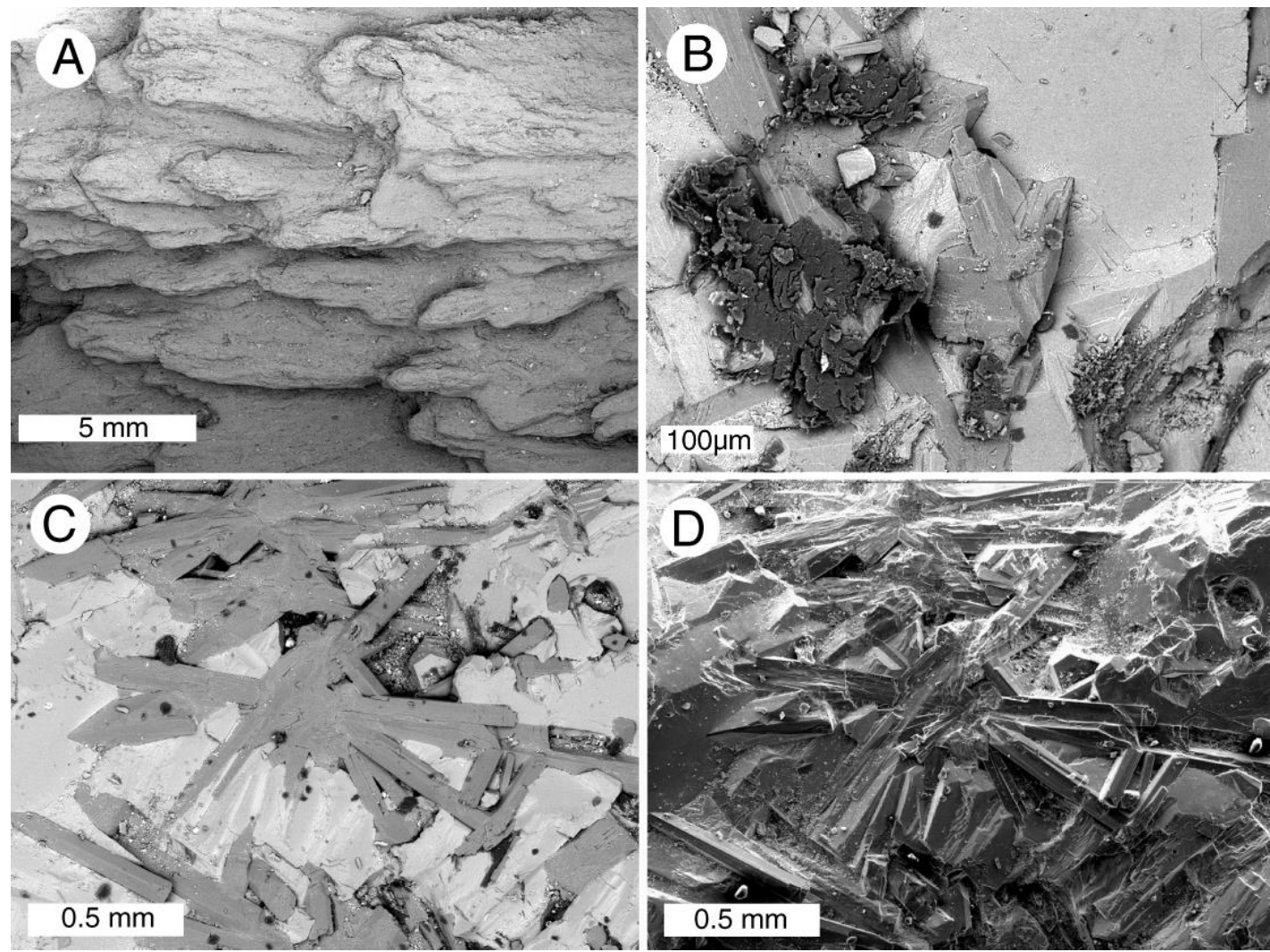

Figure 31. SEM images of Mount Elgon fossil wood. (A) Exterior view of limb showing relict wood grain texture mineralized with stilbite; (B) patches of relict organic matter (dark gray within matrix of stilbite (medium gray) and calcite (light gray); (C) interlocking crystals of stilbite (medium gray) and calcite (light gray); (D) Backscattered electron image of the same field of view, showing prismatic crystal habit. Specimens provided by Jim Mills.

\section{Discussion}

The above examples are evidence of the diverse geologic conditions that can cause wood fossilization. Factors that govern mineralization include availability of various dissolved elements in groundwater, $\mathrm{pH}, \mathrm{Eh}$, and temperatures and pressures during diagenesis. Solubilities differ greatly among various elements and compounds; monovalent ions such as $\mathrm{Na}$ and $\mathrm{K}$ have higher solubility than multivalent ions, e.g., $\mathrm{Ca}, \mathrm{Cu}$, and $\mathrm{Fe}$. Because precipitation and dissolution of minerals involves multiple chemical and physical factors, two-dimensional phase diagrams have limitations for depicting factors that affect wood petrifaction. However, experimental data can provide useful insights. The following discussion is by no means a thorough presentation of geochemical factors that control wood mineralization. Instead, the focus is on conditions that relate to the formation of some of the most common types of non-silica fossil wood.

\subsection{Calcite and Dolomite}

The near-surface pressures and temperatures, the precipitation and dissolution of calcite and silica is strongly influenced by $\mathrm{pH}$ (Figure 32) When both elements are available, wood may be silicified at low $\mathrm{pH}$, while calcite mineralization occurs at higher $\mathrm{pH}$ values. These stability ranges explain why fossil wood seldom contains both minerals. 


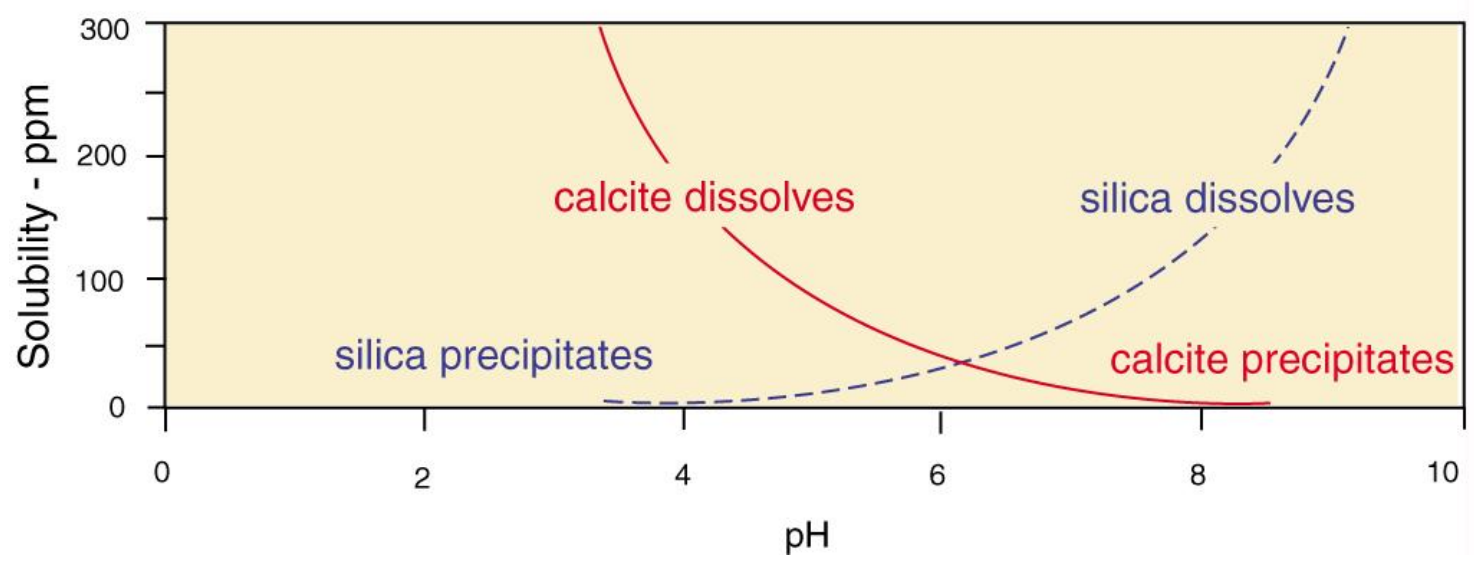

Figure 32. Solubility of calcite and silica at $25^{\circ} \mathrm{C}$. Data adapted from $[81,82]$.

The scarcity of dolomite in carbonite mineralized wood is likewise explained by the observation that even when dissolved $\mathrm{Mg}$ levels are high, dolomite precipitation only occurs at warm temperatures (Figure 33).

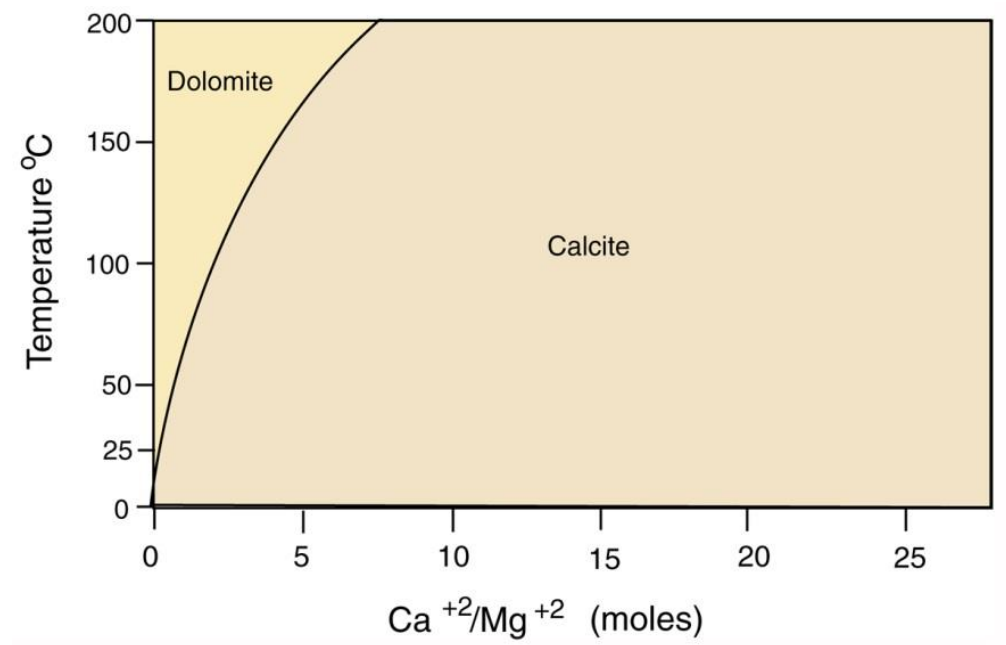

Figure 33. Precipitation of calcite and dolomite, $\mathrm{pH}=7$. Data adapted from [83].

\subsection{Iron Minerals}

Mineralization of wood with iron minerals involves multiple factors (Figure 34). Reducing conditions favor precipitation; anaerobic degradation of organic matter commonly produces a reducing environment, but pyrite/marcasite $\left(\mathrm{FeS}_{2}\right)$ formation also requires availability of dissolved sulfur. The narrow stability field for pyrrhotite ( $\mathrm{FeS}$ ) explains why this mineral has not been found in fossil wood). Formation of hematite $\left(\mathrm{Fe}_{2} \mathrm{O}_{3}\right)$ and magnetite $\left(\mathrm{Fe}_{3} \mathrm{O}_{4}\right)$ are separated by a relatively narrow Eh difference, but $\mathrm{pH}$ is an important factor. At near-neutral $\mathrm{pH} /$ mildly oxidizing Eh conditions typical of many shallow-depth diagenetic environments, if dissolved iron is available, ferric iron minerals (e.g., hematite and göethite) are favored. The diagram (Figure 34) does not provide information for the petrogenesis of siderite $\left(\mathrm{FeCO}_{3}\right)$, a common constituent of ferruginous fossil wood. A fundamental requirement for siderite precipitation is availability of both dissolved iron and carbonate ions. Phase relations for iron minerals in lacustrine environments are shown in Figure 35. Siderite precipitates in a near-neutral $\mathrm{pH}$ and moderately negative Eh range, which is commonly attainable in natural environments, involving, so the most important requirement is availability of dissolved carbonate and iron. Degradation of organic matter can provide both the reducing environment and the supply of 
$\mathrm{CO}_{3}{ }^{2-}$. Siderite precipitation is favored if dissolved sulfur is absent, preventing formation of pyrite or pyrhottite; vivianite precipitation requires availability of dissolved phosphorus. When phosphorus is present, apatite is a more likely precipitate of dissolved calcium is present. For this reason, wood is rarely mineralized with vivianite, the most common occurrences being as powdery coatings on Pleistocene and Holocene decayed or carbonized wood [84], not as wood replacement (Figure 36).

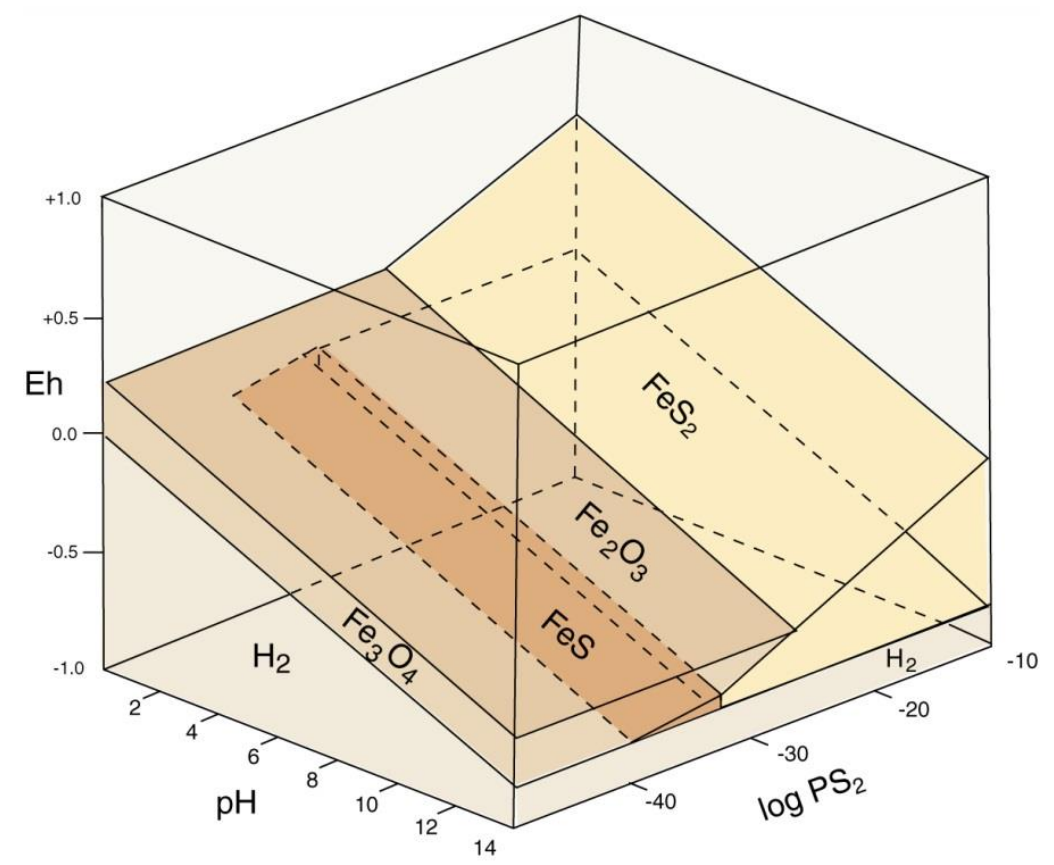

Figure 34. Phase diagram for common iron sulfide and oxide minerals. Reprinted from [38].

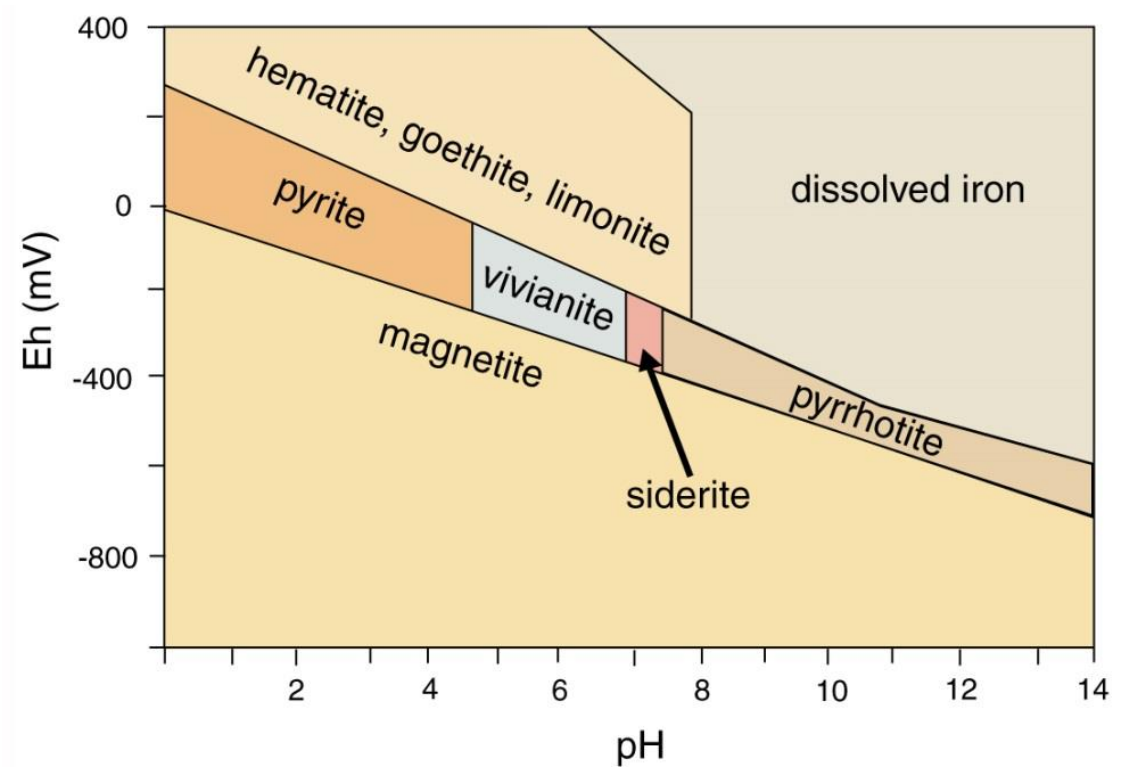

Figure 35. Phase relations for iron mineral in lacustrine environments. Plot based on data from $[85,86]$. Stability fields are affected by elemental availability, e.g., sulfides pyrite and pyrhottite precipitation requires sulfur, vivianite requires phosphorous. 


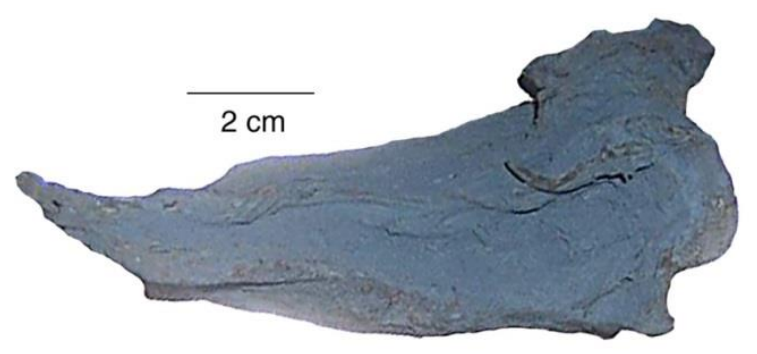

Figure 36. Pleistocene wood coated with vivianite, $\mathrm{Fe}_{3}\left(\mathrm{PO}_{4}\right)_{2} \cdot 8 \mathrm{H}_{2} \mathrm{O}$, locality unknown.

\subsection{Calcium Phosphate}

Phosphatic wood mineralization requires a source of soluble phosphate and carbonate. These components are common in marine environments, sometimes producing extensive phosphorite deposits [87]. Reports of phosphatized wood commonly describe occurrences in marine sediments [10,21-23]. Phosphatized wood is also known from terrestrial and lacustrine environments [2,20,26-30], where the source of phosphorus is more difficult to interpret. Phosphorus has been described as the 10th [31] or 11th [32] most abundant element in the Earth's crust, but under pristine conditions this element is typically present only at low concentrations. In many modern environments, elevated levels result from anthropogenic sources: agricultural fertilizer, leaking septic systems, and animal manure. Phosphorus is an essential micronutrient for all living organisms, required for making cell membranes, nucleic acids, and adenosine triphosphate (ATP). Phosphorus enters the food chain through primary producers who obtain this element both from the residues of organisms and from the weathering of phosphate-containing minerals. All consumers obtain their phosphorus from ingesting other organisms. For example, many fish consume insects, fish-eating birds produce guano, and that guano may be released into the environment. Like other forms of mineral precipitation, the phosphatization of wood requires appropriate chemical conditions $(\mathrm{pH}$, Eh, temperature, etc.), but these conditions are well within the ranges found in many diagenetic environments. When dissolved $\mathrm{Ca}$ and $\mathrm{P}$ are both available, calcium phosphate precipitation occurs at near-neutral $\mathrm{pH}$ conditions [88]. $\mathrm{Ca}^{+2}$ is relatively abundant in natural waters, and the scarcity of dissolved phosphorus in non-marine environments the rarity of phosphatized wood. In continental deposits, possible phosphorus sources include abundant insect remains, bird guano, or vertebrate material. However, a more likely source is weathering of phosphate-rich bedrock.

\subsection{Copper Minerals}

The origin of copper mineralized woods commonly begins when copper-bearing brines infiltrate buried plant remains, where degradation of organic materials produces a localized reducing environment. The first mineral to precipitate is typically chalcocite, sometimes accompanied by chalcopyrite, bornite, or cuprite. These copper minerals replace wood tissue. Later oxidation at nearsurface conditions causes alteration of the primary minerals to produce secondary compounds that include malachite, azurite, and chryscolla [56-59,61,62]. This type of supergene alteration is a common feature of copper ore deposits, the unusual aspect at Nacimiento being the abundance of fossil wood.

\subsection{Other Minerals}

Woods mineralized with clay or zeolite minerals have received little study. The mineralogy may sometimes be the result of alteration of earlier phases. Zeolite crystals have previously been reported as a component of silicified wood preserved in volcanic ash, where diagenetic alteration of the volcaniclastic matrix results in formation of zeolites within cell lumen in areas of the wood in proximity to the matrix [3]. Natrolite-replaced wood at Mount Elgon, Uganda may be an example of a similar diagenetic process, developed at a much greater extent. Fluorite mineralization of wood at Chemnitz is a particularly enigmatic occurrence, a type of petrifaction not found at any other locality. 


\subsection{Highly-Localized Geochemical Conditions}

Many localities contain petrified wood where all specimens have similar composition, but at other sites mineralization is highly variable. Variations in permeability of the host sediment may cause heterogeneous infiltration of mineral-laden groundwater, and Eh and $\mathrm{pH}$ conditions may be subject to localized presence of decomposing organic matter. As previously noted, one example is the Gooch Table site at Virgin Valley, Nevada, USA, where opalized wood specimens are abundant in a stratum that contains small amounts of wood replaced by apatite (Figure 7A,B), and by iron-manganese oxide (Figures 9C and 14).

\subsection{Multiple Episodes of Mineralization}

When wood becomes petrified, the process of mineralization may proceed in single event, or as a series of episodes. In the latter case, if compositions of pore fluids fluctuate, if Eh or $\mathrm{pH}$ conditions shift, or if burial temperatures change, complex mineral assemblages may be produced. This variation is well-documented for $\mathrm{SiO}_{2}$ polymorphs silicified wood $[3,89,90]$. The potential for [16] compositional variation may be even greater for non-silica petrified wood, where multivalent ions have the capacity for several oxidation states, and where wood replacement is not dominated by organic templating of silica in cell walls, where mineral precipitation is related to the stereochemistry of functional groups organic constituents of wood tissue. Woods mineralized with Fe or $\mathrm{Cu}$ are good examples of this complexity, where wood may be replaced by metal sulfides, oxides, or carbonates, either alone or in combination.

\subsection{Possibilities for Future Research}

In all paleontology research, investigations are often based on discoveries of new specimens. These discoveries may that may be a product of painstaking field work or simply pure luck. Studying the mineralogy of fossil wood involves some additional factors. Investigations of fossil wood have commonly been conducted by paleobotanists, who typically focus on taxonomic and paleoenvironmental interpretations. Microscopic examinations are commonly performed using biological microscopes, which may reveal exquisite anatomical detail but provide little if any evidence of mineral composition, information that may be readily obtainable if the same specimens are viewed using a petrographic microscope. Ideally, fossil wood research would be an interdisciplinary adventure involving cooperation of botanists and mineralogists. A second issue is that prior to the advent of modern instrumental methods, determining the mineral composition of fossil wood has been difficult. Miocene wood at Bruneau, Idaho, USA is a good example. Thousands of specimens have collected over a span of half a century. These fossil limbs were recognized as being non-silicified because of their low hardness, and in the absence of analytical data they were described in as being mineralized with calcite and gypsum [91]. In 2017, the Bruneau wood was finally correctly identified as being composed of carbonate-fluorapatite based on XRD and SEM/EDS data [28]. In summary, future research can follow two possible paths: a search for new fossil sites, and careful analyses of specimens in museums and research collections.

Acknowledgments: I thank the following people for donating specimens for this study: Graham Beard, Gerald Cranham, Tad Dillhoff, and Jim Mills. Photos and other data were generously provided by Tad Dillhoff, Linda Reinink-Smith, Ronny Rößler, and Mike Viney. Muharrem Yavuz provided English translations of the Turkish newspaper article on "colla wood" [63]. Ronny Rößler deserves special thanks for his expertise and careful attention to detail during preparation of the manuscript. Two anonymous reviewers provided many helpful suggestions.

Conflicts of Interest: The author declares no conflicts of interest. 


\section{References}

1. Mustoe, G.E. Wood petrifaction: A new view of permineralization and replacement. Geosciences 2017, 7, 119. [CrossRef]

2. Buurman, P. Mineralization of fossil wood. Scr. Geol. 1972, 12, 1-43.

3. Mustoe, G.E. Late Tertiary petrified wood from Nevada, USA: Evidence of multiple silicification pathways. Geosciences 2015, 5, 286-309. [CrossRef]

4. Matysova, P.; Rössler, R.; Götze, J.; Leichmann, J.; Forbes, G.; Taylor, E.L.; Sakala, J.; Grygar, T. Alluvial and volcanic pathways to silicified plant stems (Upper Carboniferous-Triassic) and their taphonomic and paleoenvironmental meaning. Paleogeogr. Paleoclimatol. Paleoecol. 2010, 292, 127-143. [CrossRef]

5. Siurek, J.; Chevallier, P.; Ro, C.; Chun, H.Y.; Youn, H.S.; Zięba, E.; Kuczumow, A. Studies on the wood tissue substitution by silica and calcite during preservation of fossil wood. J. Alloys Compd. 2004, 362, $107-115$. [CrossRef]

6. Greenland, C.W. The replacement of wood by calcite. Econ. Geol. 1918, 13, 116-119. [CrossRef]

7. Galwitz, H. Verkalung undVerkisalung von Hőlzern in der Braunkhohle des Geiseltales. Wiss. Z. Univ. Halle, Math. Nat. 1954, 4, 41-44.

8. Francis, J.E. Arctic Eden. Nat. Hist. 1991, 100, 57-62.

9. Boyce, C.K.; Hazen, R.M.; Knoll, A.H. Nondestructive, in situ, cellular-scale mapping of elemental abundances in permineralized fossils. Proc. Nat. Acad. Sci. USA 2001, 98, 5970-5974. [CrossRef] [PubMed]

10. Scott, A.C.; Collinson, M.E. Non-destructive multiple approaches to interpret the preservation of plant fossils: Implications for calcium-rich permineralizations. J. Geol. Soc. Lond. 2003, 160, 857-862. [CrossRef]

11. Higgins, C.G. Calcification of some California Cretaceous wood. Geol. Soc. Am. Bull. 1960, 71, 1887-1888.

12. Higgins, C.G. Significance of some fossil wood from California. Science 1961, 134, 473-479. [CrossRef] [PubMed]

13. Lange, P.; Steiner, W. Rasterelektronenmikroskopische Untersuchungn an verkaltyen Holzresten aus dem plesitozaenen Travertin von Weimar. Quartaepalaeontologie 1984, 5, 225-236.

14. Brand, L.S. Calcified wood found in Pleistocene sand. Ohio Acad. Sci. Proc. 1930, 8, 409.

15. Brand, L.S. Calcified wood in upland sand near Cincinnati. Ohio J. Sci. 1932, 32, 55-62.

16. Lorenz, V.J.; Rößler, R.; Schmitt, R.T. Fossiles Holz aus Fluorapatit und Calcit von der Tjörnes-Halbinsel, Nord-Island. Der Aufscluss 2010, 8, 17-25.

17. Schwab, G. Über dolomitisiertes Holz aus der Weichbraunkohle von Malliss (Mecklenburg). Monatsber. Deutsch. Akad. Wiss. Berlin 1959, 1, 761-767.

18. Vadász, E. Geological problems of fossil wood in Hungary. Acta Geol. Acad. Sci. Hung. 1964, 8, 119-143.

19. Mustoe, G.E. Density and loss on ignition as indicators of the fossilization of silicified wood. IAWA J. 2016, 37, 98-111. [CrossRef]

20. Bucovic, W.A. The Eocene Deltaic System of the Coal-Bearing Puget Group of Western Washington. In Cenozoic Paleogeography of the Western United States, Pacific Coast Paleogeography Symposium 3; Armentrout, J.M., Cole, M.R., TerBest, H., Eds.; The Pacific Section Society of Economic Paleontologists and Mineralogists: Los Angeles, CA, USA, 1979; pp. 147-163.

21. Reolid, M.; Phillipe, M.; Nagy, J.; Abad, I. Preservation of phosphatic wood remains in marine deposits of the Brentskardhaugen Bed (Middle Jurassic) from Svalbard (Boreal Realm). Facies 2010, 56, 459-466. [CrossRef]

22. Krajewski, K.P. Organic geochemistry of a phosphorite to black shale transgressive succession: Wilhelmøya and Janusfjellet Formations (Rhaetian-Jurassic) in Central Spitsbergen, Arctic Ocean. Chem. Geol. 1989, 74, 249-263. [CrossRef]

23. Goldberg, E.D.; Parker, R.H. Phospatized wood from the Pacific sea floor. Geol. Soc. Am. Bull. 1960, 71, 631-632. [CrossRef]

24. Arena, D.A. Exceptional preservation of plants and invertebrates by phosphatization, Riversleigh, Australia. Palaios 2008, 23, 495-502. [CrossRef]

25. Glukoster, H.J.; Pierard, L.H.; Pfefferkorm, H.W. Apatite petrifactions in Pennsylvanian shales of Illinois. J. Sediment. Res. 1970, 40, 1363-1366.

26. Jefferson, T.H. The preservation of conifer wood: Examples from the Lower Cretaceous of Antarctica. Paleontology 1987, 30, 233-249. 
27. Sweeney, I.J.; Chin, K.; Hower, J.C.; Budd, D.A.; Wolfe, D.G. Fossil wood from the middle Cretaceous Moreno Hill Formation: Unique expressions of wood mineralization and implications for the processes of wood preservation. Int. J. Coal Geol. 2009, 78, 1-17. [CrossRef]

28. Viney, M.; Mustoe, G.E.; Dillhoff, T.A.; Link, P.S. The Bruneau Woodpile: A Miocene phosphatized wood locality in southwestern Idaho, USA. Geosciences 2017, 7, 82. [CrossRef]

29. Pailler, D.; Flicoteaux, R.; Ambrosi, J.P.; Medus, J. The Mio-Pliocene fossil woods from Nkondo (Lake Albert, Uganda), mineral composition and formation. C. R. Acad. Bulgare Sci. Série II Fascicule A 2000, 331, 279-286.

30. Koenigeur, J.C. Sur une liane plio-quatrinaire du Tchad. Bull. Mus. Natn. Hist. Nat. Sci. de la Terre 1973, 172, 81-91.

31. Fleischer, M. Recent Estimates of the Abundances of Elements in the Earth's Crust; U.S. Geological Survey Circular 285; USGS: Reston, VA, USA, 1953; pp. 1-3.

32. Wedepohl, K.H. The composition of the continental crust. Geochim. Cosmochim. Acta 1995, 59, 1217-1232.

33. Garcia-Guinea, J.; Martinez-Frias, J.; Harffy, M. Cell-hosted pyrite framboids in fossil woods. Naturwissenschaften 1988, 85, 78-81. [CrossRef]

34. Tibbs, S.L.; Briggs, D.E.G.; Prossl, K.F. Pyritization of plant fossils from the Devonian Hunsrück Slate of Germany. Palaeontol. Z. 2003, 77, 241-246. [CrossRef]

35. Briggs, D.E.G.; Raiswll, R.; Bottrell, S.H.; Hatfield, D.; Bartels, C. Controls on the pyriitization of exceptionally preserved fossils: An analysis of the Lower Devonian Hunstrück slate of Germany. Am. J. Sci. 1996, 296, 633-663. [CrossRef]

36. Strullu-Derrien, C.; Kenrick, P.; Tafforeau, P.; Cochard, H.; Bonnemain, J.; Le Hérisse, A.; Lardeux, H.; Badel, E. The earliest wood and its hydraulic properties documented in c. 407-million-year-old fossils using synchroton microrotomography. Bot. J. Linnean Soc. 2014, 175, 423-437. [CrossRef]

37. Kenrick, P.; Edwards, D. Anatomy of the Lower Devonian Gosslingia breconensis Heard based on pyritised axes with some comments on the permineralization process. Bot. J. Linnean Soc. 1988, 97, 95-123.

38. Mustoe, G.E.; Viney, M. Mineralogy of Paleocene wood from Cherokee Ranch fossil forest, central Colorado, USA. Geosciences 2017, 7, 23. [CrossRef]

39. Grimes, S.T.; Brock, F.; Rickard, D.; Davies, K.L.; Edwards, D.; Briggs, D.E.G.; Parkes, R.J. Understanding fossilization: Experimental pyritization of plants. Geology 2001, 29, 123-126. [CrossRef]

40. Grimes, S.T.; Davies, K.L.; Butler, I.B.; Brock, F.; Edwards, D.; Rickard, D.; Briggs, D.E.G.; Parkes, R.J. Fossil plants from the Eocene London Clay: The use of pyrite textures to determine the mechanism of pyritization. J. Geol. Soc. 2002, 159, 493-501. [CrossRef]

41. Roberts, L.B. Petrified wood composed of iron oxide. J. Geol. 1940, 48, 212-213. [CrossRef]

42. Daber, R. Betrachtung über Markasitisierung eines Koniferenholzes aus dem Miozän der Tongrube von Guttau, Kries Bautzen. Geologie 1953, 2, 263-265.

43. Martin-Penela, A.J.; Barregan, G. Silicification of plant remains in Messinian marine sediments in the Vera Basin (Almeria, Spain). Ecolgae Geol. Helv. 2003, 88, 557-593.

44. Turner, J.P.; Saunders, J.A.; Cook, R.B. Petrographic evidence for amorphous silica precursors and geomicrobiologic processes in silicified and pyritized Holocene wood. In Proceedings of the Geological Society of America Annual Meeting, Denver, CO, USA, 27-30 October 2002; p. 493.

45. Henstra, S.; Buurman, P.; Thiel, F. Investigation of fossilization processes in wood with the scanning electron microscope. JEOL News 1973, 10,1-2.

46. Scurfield, G. Wood petrifaction: An aspect of biomineralogy. Aust. J. Bot. 1979, 27, 377-390. [CrossRef]

47. Nowak, J.; Florek, M.; Kwiatek, W.M.; Kuczumow, A. Composite structure of wood cells in petrified wood. Mater. Sci. Eng. C-Mater. Biol. Appl. 2007, 25, 119-130. [CrossRef]

48. Hassan, K.M. The iron mineralogy of Eocene fossil wood-A Mőssbauer study of samples from the petrified forest, New Cairo, Egypt. Can. Mineral. 2015, 53, 705-716. [CrossRef]

49. Schellenberg, S.A. Mazon Creek: Preservation in late Paleozoic deltaic and marginal marine environments. In Exceptional Fossil Preservation: A Unique View on the Evolution of Marine Life; Etter, W., Hagadorn, J.W., Tang, C.M., Bottjer, D.J., Eds.; Columbia University Press: New York, NY, USA, 2002; pp. 185-203.

50. Williams, C.J.; Trostle, K.D.; Sunderlin, D. Fossil wood in coal-forming environments of the Late PaleoceneEarly Eocene Chickaloon Formation. Paleogeogr. Paleoclimatol. Paleoecol. 2010, 295, 363-375. [CrossRef]

51. Reinink-Smith, L.; Leopold, E.B. Warm climate in the Late Miocene of the south coast of Alaska and the occurrence of Podocarpaceae pollen. Palynology 2005, 29, 205-262. [CrossRef] 
52. Hayes, J.B.; Harms, J.C.; Wilson, T., Jr. Contrasts between braided and meandering stream deposits, Beluga and Sterling Formations (Tertiary), Cook Inlet, Alaska. In Recent and Ancient Sedimentary Environments in Alaska, Proceedings of the Alaska Geological Society Symposium, Anchorage, AL, USA, 2-4 April 1975; Miller, T.P., Ed.; Alaska Geological Society: Anchorage, AL, USA, 1976; pp. J1-J27.

53. Polgári, M.; Phillipe, M.; Szabo-Drubina, M.; Tóth, M. Manganese-impregnated wood from a Toarcian manganese deposit, Eplény Mine, Bakony Mtns., Hungary. N. Jb. Geol. Paläont. Mh. 2005, 200, 175-192.

54. Scurfield, G.; Segnit, E.R. Petrifaction of wood by silica minerals. Sediment. Geol. 1984, 39, 149-167. [CrossRef]

55. Leo, R.F.; Barghoorn, E.S. Silicification of Wood. Bot. Mus. Lealf. Harv. Univ. 1976, 25, 1-47.

56. Talbott, L.W. Nacimiento Pit, A Triassic Strata-Bound Copper Deposit. In Ghost Ranch, New Mexico Geological Society Guidebook 25; Siemens, C.T., Woodward, L.A., Callender, L.A., Eds.; New Mexico Geological Society: Socorro, NM, USA, 1974; pp. 301-303.

57. Woodward, L.A.; Kaufman, W.H.; Schumacher, D.L. Sandstone copper deposits. In Ghost Ranch, New Mexico Geological Society Guidebook 25; Siemens, C.T., Woodward, L.A., Callender, L.A., Eds.; New Mexico Geological Society: Socorro, NM, USA; pp. 295-299.

58. Woodward, L.A.; Kaufman, W.H.; Schumacher, D.L. Strata-bound copper deposits in Triassic sandstone of Sierra Nacimiento. N. M. Econ. Geol. 1974, 69, 108-120. [CrossRef]

59. Woodward, L.A. Geology and Mineral Resources of Sierra Nacimiento and Vicinity, New Mexico; New Mexico Bureau of Mines and Mineral Resources: Socorro, NM, USA; 1987; 84p.

60. Cowart, J.B.; Milne, J.J. Remediation of 25 million gallons of acidic groundwater, Nacimiento Copper Mine site, Cuba, New Mexico. In Proceedings of the 11th Tailings and Mine Wastes Conference, Vail, CO, USA, 10-13 October 2004; pp. 167-172.

61. Suneson, N.H. Petrified wood in Oklahoma, Oklahoma Geological Survey Information Series 14, Norman, Oklahoma, USA, 2010, p. 19. Available online: http:/ / www.ogs.ou.edu/geology/pdf/PetWoodIS_14,pdf. pdf (accessed on 21 December 2017).

62. Fay, O. Bibliography of Copper Occurrences in Pennsylvanian and Permian Red Beds and Associated Rocks in Oklahoma, Texas, and Kansas (1805-1996); Oklahoma Geological Survey Special Publication 2000-1; Oklahoma Geological Survey: Norman, Oklahoma, 2000; p. 16.

63. Gönder, Y. Zile opalized cola wood. Veni Tokat, 30 August 2014; p. 5. (In Turkish)

64. Akkemik, U.; Türkoğlu, N.; Poole, I.; Çiçek, I.; Köse, N.; Gürgen, G. Woods of a Miocene petrified forest near Ankara, Turkey. Turk. J. Agric. For. 2008, 33, 89-97.

65. Witke, K.; Götze, J.; Rößler, R.; Dietrich, D.; Marx, G. Raman and cathodoluminescence spectroscopic investigation on Permian fossil wood from Chemnitz-a contribution to the study of the permineralization process. Spectrochem. Acta Part A 2004, 60, 2903-2913. [CrossRef] [PubMed]

66. Rößler, R. Two remarkable Permian petrified forests: Correlation, comparison, and significance. In Non-Marine Permian Biostratigraphy and Biochronology; Lucas, S.G., Cassinis, G., Schneider, J.W., Eds.; Special Publications: London, UK, 2006; Volume 265, pp. 48-53.

67. Rößler, R.; Annacker, V.; Kretzschmar, R.; Eulenberger, S.; Tunger, B. Auf Schatzsuche in ChemnitzWissenschaftliche Grabungen '08. Veröffentlichungen Museum Naturkunde 2008, 31, 5-44.

68. Läbe, S.; Gee, C.T.; Ballhaus, C.; Nagel, T. Experimental silicification of the tree fern Dicksonia antarctica at high temperature with silica-enriched $\mathrm{H}_{2} \mathrm{O}$ vapor. Palaios 2012, 27, 835-841. [CrossRef]

69. Luthardt, L.; Rößler, R.; Schneider, J.W. Palaeoclimatic and site-specific conditions in early Permian fossil forest of Chemnitz-Sedimentological, geochemical and palaeobotanical evidence. Palaeogeogr. Palaeoclimatol. Palaeoecol. 2016, 441, 627-652. [CrossRef]

70. Schmidt, E. Unbekannte Fundstellen rund um Sobernheim/Nahe. Aufschluß 1979, 11, 383-388.

71. Winckler, K.M. "Hülsenfrüchte” aus dem Oligozän—Die Grube Steinhardt bei Sobernheim. Fossilien 1984, 6, 253-257.

72. McConnell, D. An American occurrence of volkonskoite. Clays Clay Miner. 1953, 2, 152-155. [CrossRef]

73. Foord, E.E.; Starkey, H.C.; Taggart, J.E.; Swawe, D.R. A reassessment of the volkonskoite-chromian smectite nomenclature problem. Clays Clay Miner. 1987, 35, 139-149. [CrossRef]

74. Oldman, O.H. Volcanic rocks of Mount Elgon in British East Africa. Geol. Fören. Förhandl. 1930, $455-537$. [CrossRef]

75. Kräusel, E.; Frankfurt, A.M. Das Alter der fossilen Hölzer vom Mt. Elgon, Brit. Ost-Africa. GIF 1934, 56, 489-492. 
76. Bancroft, H. Some fossil dicotyledonous woods from Mount Elgon, East Africa I. Am. J. Bot. 1935, 22, $164-183$. [CrossRef]

77. Bancroft, H. Some fossil dicotyledonous woods from Mount Elgon, East Africa II. Am. J. Bot. 1935, 22, 279-290. [CrossRef]

78. Bancroft, H. The Stockholm collections of fossil woods from Mount Elgon: Supplementary note. GFF 1936, 58, 393-396. [CrossRef]

79. Bloomfield, K. Carbonatite-derived sediments in southeast Uganda. J. Geol. Soc. Lond. 1972, 128, 507-511. [CrossRef]

80. Davies, K.A. The building of Mount Elon (East Africa). In Geological Survey of Uganda Memoir VII; Benham and Company: Colchester, UK, 1952; 72p.

81. Utami, W.S.; Herdianita, N.R.; Atmaja, R.W. The Effect of Temperature and pH on the Formation of Silica Scaling of Dieng Geothermal Field, Central Java, Indonesia. In Proceedings of the Thirty-Ninth Workshop on Geothermal Reservoir Engineering Stanford University, Stanford, CA, USA, 24-26 February 2014.

82. Nicholson, K. Geothermal Fluids: Chemistry and Exploration Techniques; Springer: Berlin, Germany, 1968; 263p.

83. Hardie, L.A. Dolomotization, a critical view of some current views. J. Sediment. Res. 1987, 57, 166-183. [CrossRef]

84. Henderson, G.S.; Black, P.M.; Rodgers, K.A.; Rankin, P.C. New data on New Zealand viviantite and metavivianite. N. Z. J. Geol. Geophys. 1984, 27, 367-378.

85. Hem, J.D. Reaction of metal ions at surfaces of hydrous iron oxides. Geochim. Cosmochim. Acta 1977, 41, 527-538. [CrossRef]

86. Lemos, V.P.; Lima da Costa, M.; Lemos, R.I.; Gomes de Faria, M.S. Vivianite and siderite in lateritic iron crust: An example of bioreduction. Quim. Nova 2007, 30, 36-40. [CrossRef]

87. McKelvey, V.E. Phosphate Deposits. In U.S. Geological Survey Bulletin 125-D; U.S. Government Publishing Office: Washington, DC, USA, 1967; 21p.

88. Chow, L.C. Solubility of Calcium Phosphates. In Octacalcium Phosphate; Chow, L.C., Eanes, E.D., Eds.; Karger: Basel, Switzerland, 2001; Volume 18, pp. 94-111. Available online: http:/ /www.bio.umass.edu/ biology/kunkel/pub/lobster/PDFs/CrystalChemistry/Chow\&Eanes_SolCaP-MOrSci2001.pdf (accessed on 21 December 2017).

89. Mustoe, G.E. Mineralogy and geochemistry of late Eocene silicified wood from Florissant Fossil Beds National Monument, Colorado. In Paleontology of the Upper Eocene Florissant Formation, Colorado; Meyer, H.W., Smith, D.M., Eds.; Geological Society of America Special Paper 35; Geological Society of America: Boulder, CO, USA, 2008; pp. 127-140.

90. Viney, M.; Dietrich, D.; Mustoe, G.E.; Link, P.; Lampke, T.; Götze, J.; Rößler, R. Multi-stage silicification of Pliocene wood: Re-examination of a 1985 discovery from Idaho, USA. Geosciences 2016, 6, 21. [CrossRef]

91. Root, J.V. Bruneau wood. Gems Miner. 1971, 409, 36-37.

(C) 2018 by the author. Licensee MDPI, Basel, Switzerland. This article is an open access article distributed under the terms and conditions of the Creative Commons Attribution (CC BY) license (http:/ / creativecommons.org/licenses/by/4.0/). 